\title{
Memorial de Imigração Polonesa em Curitiba: dinâmicas culturais e interesses políticos no âmbito memoralista
}

\section{Sandra Paschoal Leite de Camargo Guedes ${ }^{1}$ Gina Esther Issberner ${ }^{2}$}

RESUMO: Neste artigo, analisa-se o conceito de memorial, considerando as atuais definições de Museu propostas pelo Conselho Internacional de Museus e pelo Instituto Brasileiro de Museus, tendo como objeto de investigação o Memorial de Imigração Polonesa de Curitiba. Evidenciam-se a importância e a complexidade no trato com o patrimônio e as dificuldades de pensá-lo a partir dos sujeitos e das referências culturais de determinado grupo em contraponto aos interesses políticos e econômicos; no caso em questão, voltadas às necessidades da política de city marketing como estratégia de construção da imagem da cidade. Para tanto, foram considerados os perfis de atuação dos memoriais em diferentes partes do mundo, na tentativa de delimitação conceitual, exemplificando-se a pluralidade de temas e formatos dessas instituições no âmbito nacional e global. As discussões levantadas permitem pensar que os Museus Memoriais desempenham as atividades de um memorial no âmbito museológico, confirmando a ambivalência dessas duas instituições e sua interface privilegiada com o poder político.

PALAVRAS-CHAVE: Memorial. Museu. Representação Política.

ABSTRACT: This article analyzes the memorial concept, considering the Museum definition presented by the International Council of Museums and the Brazilian Institute of Museums. The aim of this study was the Curitiba Polish Immigration Memorial. It highlights the importance and complexity in dealing with the heritage and the difficulties of thinking it from the individuals and the cultural references of certain groups as opposed to political and economic interests; in this case the needs of the city marketing policy as city image building strategy. Therefore, the memorials performance profiles in different parts of the world in an attempt to conceptual definition, exemplifying the diversity of themes and formats of these institutions at the national and global levels. The discussions show that it is possible to consider that the Memorials Museums perform the same activities of a memorial within the museological context, confirming the ambivalence of these two institutions and prime interface with political power.

\begin{abstract}
1. Docente do Programa de Mestrado em Patrimônio Cultural e Sociedade da Universidade da Região de Joinville - Univille. E-mail: <sandraplcguedes@gmail. com>.

2. Museóloga da Universidade Estadual de Londrina. Centro de Ciências Humanas. E-mail: <gina. issberner@uel.br>.
\end{abstract}

KEYWORDS: Memorial. Museum. Political Representation. 
3. A Missão Polonesa no Brasil foi criada em 1953 para dar amparo aos imigrantes católicos de origem polonesa no Brasil.

4. Oliveira (2009, p. 230).
Introdução

Memorial da Imigração Polonesa - MIP, equipamento cultural administrado pela Prefeitura de Curitiba, em conjunto com a Missão Polonesa no Brasil, ${ }^{3}$ está situado no Bosque Estadual João Paulo II, popularmente conhecido como Bosque do Papa. Inaugurado em dezembro de 1980, sua localização corresponde a uma região nobre da cidade de Curitiba, em bairro de alto poder aquisitivo onde, posteriormente (2002), também foi construído um dos principais museus da cidade, o Museu Oscar Niemeyer.

Formado por sete casas de troncos provenientes de antigas colônias de imigrantes poloneses, distribuídas no Bosque, o MIP procura ser um elemento catalizador na transmissão e difusão de saberes que envolvem a arte, a religiosidade e os costumes de uma das maiores correntes migratórias que vieram para a capital paranaense. Segundo Oliveira, cerca de 40 mil poloneses chegaram ao Paraná entre 1870 e 1914, fazendo deste estado o "que mais recebeu imigrantes desse grupo". ${ }^{4}$

Os parques e memoriais étnicos fazem parte do complexo urbano de Curitiba, servindo como símbolos de uma cidade que se orgulha da grande área verde que possui no perímetro urbano e da atenção que dá à formação histórica de sua população. Além do Memorial dedicado à imigração polonesa, foco deste artigo, Curitiba possui outros seis memoriais: o Memorial da Cultura Japonesa (1993 - Praça do Japão), o Memorial Ucraniano (1994 - Parque Tingui), o Memorial da Língua Portuguesa (1994 - Bosque de Portugal), o Memorial de Imigração Alemã ( 1996 - Bosque Alemão) o Memorial da Imigração Árabe (1996 - Praça Gibran Khalil Gibran) e o Memorial de Imigração italiana ( 1996 - Bosque São Cristóvão).

Dentro dessa realidade, pergunta-se: qual o conceito de memorial utilizado para a implantação daquela instituição? $\bigcirc$ Memorial da Imigração Polonesa pode ser considerado um museu, como sugerem as atuais definições do Conselho Internacional de Museus - ICOM, pelo Instituto Brasileiro de Museus IBRAM? Para procurar responder a essas questões, serão apresentados o Memorial de Imigração Polonesa e algumas discussões sobre o processo de criação deste Memorial em Curitiba e a respeito do conceito de memorial, não só no Brasil como também em outras partes do mundo.

A estrutura do Memorial da Imigração Polonesa - MIP

nome do bosque onde está situado o MIP remete à visita feita pelo papa polonês, João Paulo II, à cidade de Curitiba, em junho de 1980, ocasião em que celebrou uma missa campal no Estádio Major Antônio Couto Pereira, bem como visitou uma casa de imigrantes poloneses, que fora remontada naquele local para o evento. Essa casa foi construída, originalmente, em 1883, na Colônia de 
imigrantes poloneses Tomás Coelho ${ }^{5}$ e foi a primeira a ser montada no Memorial da Imigração Polonesa. No Memorial, essa casa, que simboliza a religiosidade dos poloneses, foi transformada em uma capela, em homenagem à Virgem Negra de Czestochowa (Figura 1), padroeira da Polônia.

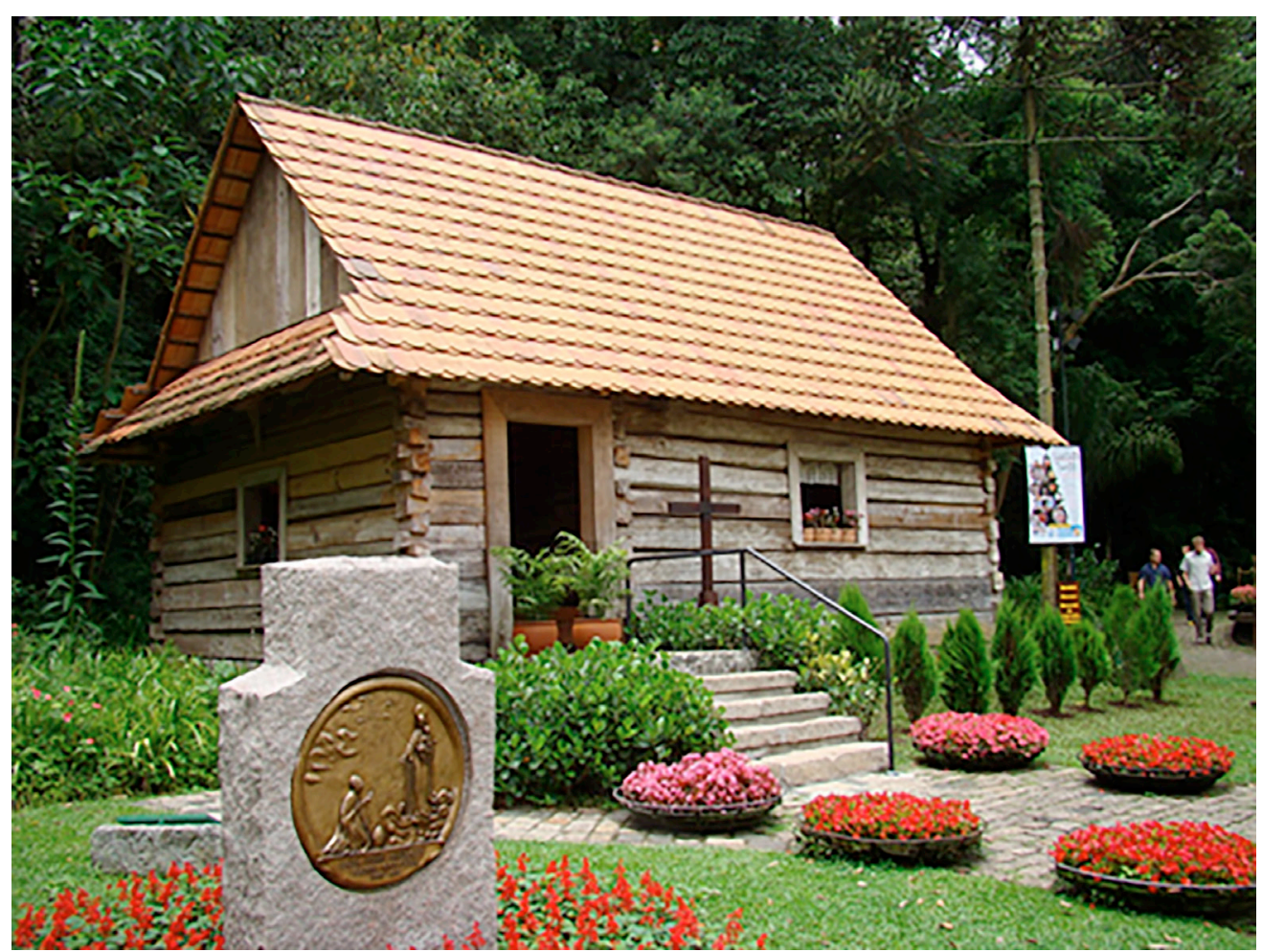

Figura 1 - Capela dedicada a Nossa Senhora de Czestochowa - MIP. Fonte: FIGUNDIO, André. Bosque do Papa em Curitiba: um passeio cultural, divertido e gratuito ${ }^{\circ}$

A presença do Papa em seu interior ressignificou a casa, que passou a ter um caráter sagrado, preservado pela capela e cultuado pelos visitantes (Figura 2).

Figura 2 - Interior da capela, ornamentada para dia de $\mathrm{N}$. $\mathrm{Sr}^{a}$ de Czestochowa, 26 de agosto Fonte: CEQUINEL, L. Memorial da Imigração Polonesa, Bosque do Papa

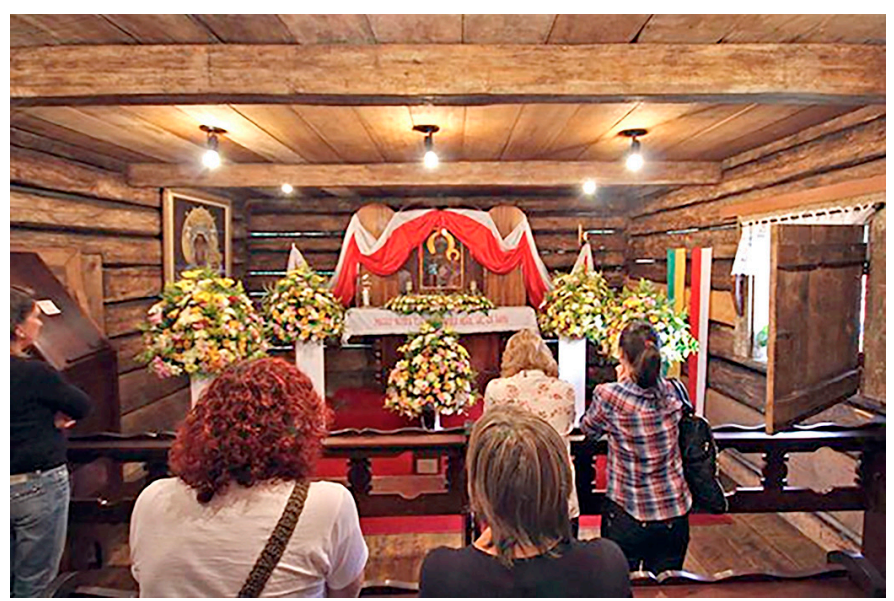

5. Trataremos do processo de transferência das casas da Colônia para o MIP no próximo item deste artigo.

6. Disponível em: <http:// euqueroeviajar.blogspot. com.br/2012/04/bosque-do-papa-em-curitiba-um-passeio.html>. Acesso em: 5 abr. 2016.

7. Disponível em <https:// b r.pinteres t . com / pin/360921357617545368/> Acesso em 5 de ago. 2016. 
8. Segundo a coordenadora dos Memoriais étnicos da Fundação Cultural de Curitiba, Maria Daici Gonçalves de Lara, não há reserva técnica no MIP e a catalogação do acervo existente se resume a uma listagem. Lara (2015).

9. Disponível em http:// www.curitiba.pr.gov.br/ fotos/album-portal-polones-marca-historia-da-imigracao-desse-povo-a-curitiba/24220. Acesso em 6 nov 2016.

10. Pintura em ovos, artesanato polonês.

11. Também chamado de matriosbka, brinquedo tradicional da Rússia. Várias bonecas de madeira, de diferentes tamanhos que se encaixam umas dentro das outras.
A edificação denominada "Museu da Habitação" foi construída no final do século XIX e é a única das sete casas existentes no MIP proveniente de outra colônia de imigrantes poloneses que não seja a Tomás Coelho, a Colônia Muricy, situada no município vizinho a Curitiba, São José dos Pinhais. $\bigcirc$ interior dessa edificação abriga uma exposição de móveis e utensílios domésticos, como cama, berços, mesa e cadeiras, entre outros.

A Figura 3 apresenta uma vista do Memorial da Imigração Polonesa, pela qual é possível ver uma praça com vários bancos para descanso e algumas das casas que compõem o Parque. Ao centro da figura, ao fundo, vê-se a Capela; à direita, a casa branca é o Museu da Habitação e, ao lado dela, ao fundo, a Administração do Bosque e loja de souvenir. Em primeiro plano, à esquerda, vê-se a lateral da casa que é utilizada pela Guarda Municipal e para armazenamento de acervo. ${ }^{8}$

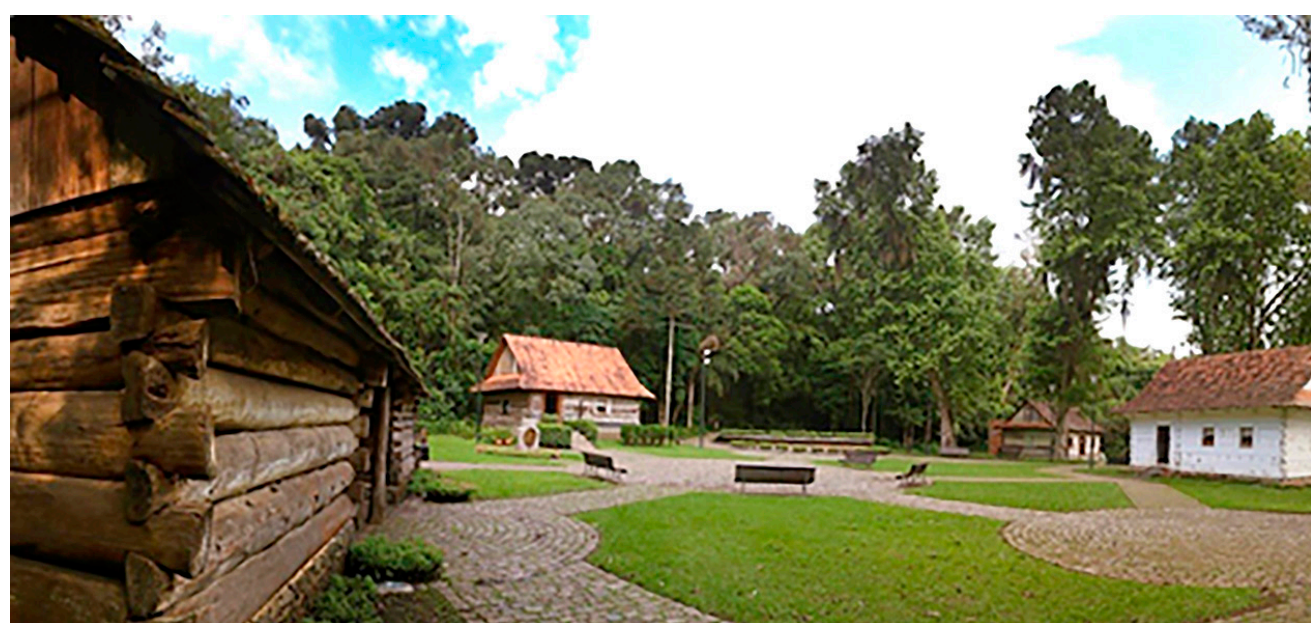

Figura 3 - Vista do Memorial da Imigração Polonesa - MIP. Fonte: Curitiba. Galeria de Imagens. ${ }^{9}$

A casa utilizada como posto da Guarda Municipal e ambiente de armazenamento de acervo foi construída em 1876, sendo também proveniente da Colônia Tomás Coelho. Já a edificação onde, atualmente, funciona uma venda de produtos típicos poloneses e a administração local do Bosque (Figura 4) serviu originalmente de moradia e paiol e foi construída em 1877.

No interior da loja, existe uma variedade de produtos de diversas procedências, formas e técnicas como pisanki, ${ }^{10}$ bonecas de palha de milho, mamuskas, ${ }^{11}$ mobiles, bordados, objetos de marchetaria, bolachas e doces. Compõe o coniunto de edificações um antigo paiol do século XIX (Figura 5), onde são abrigados alguns objetos provenientes da antiga colônia de imigrantes, como carroças, rodas e partes de equipamentos agrícolas, sem uma temática específica.

Fazem parte, ainda, do MIP, uma edificação construída em 1852 utilizada atualmente para a exposição de objetos agrícolas, como o arado, a mó para cereais e a tina de lavar roupas - e aquela utilizada como Casa de Eventos do Memorial, onde ocorrem exposições temporárias. 


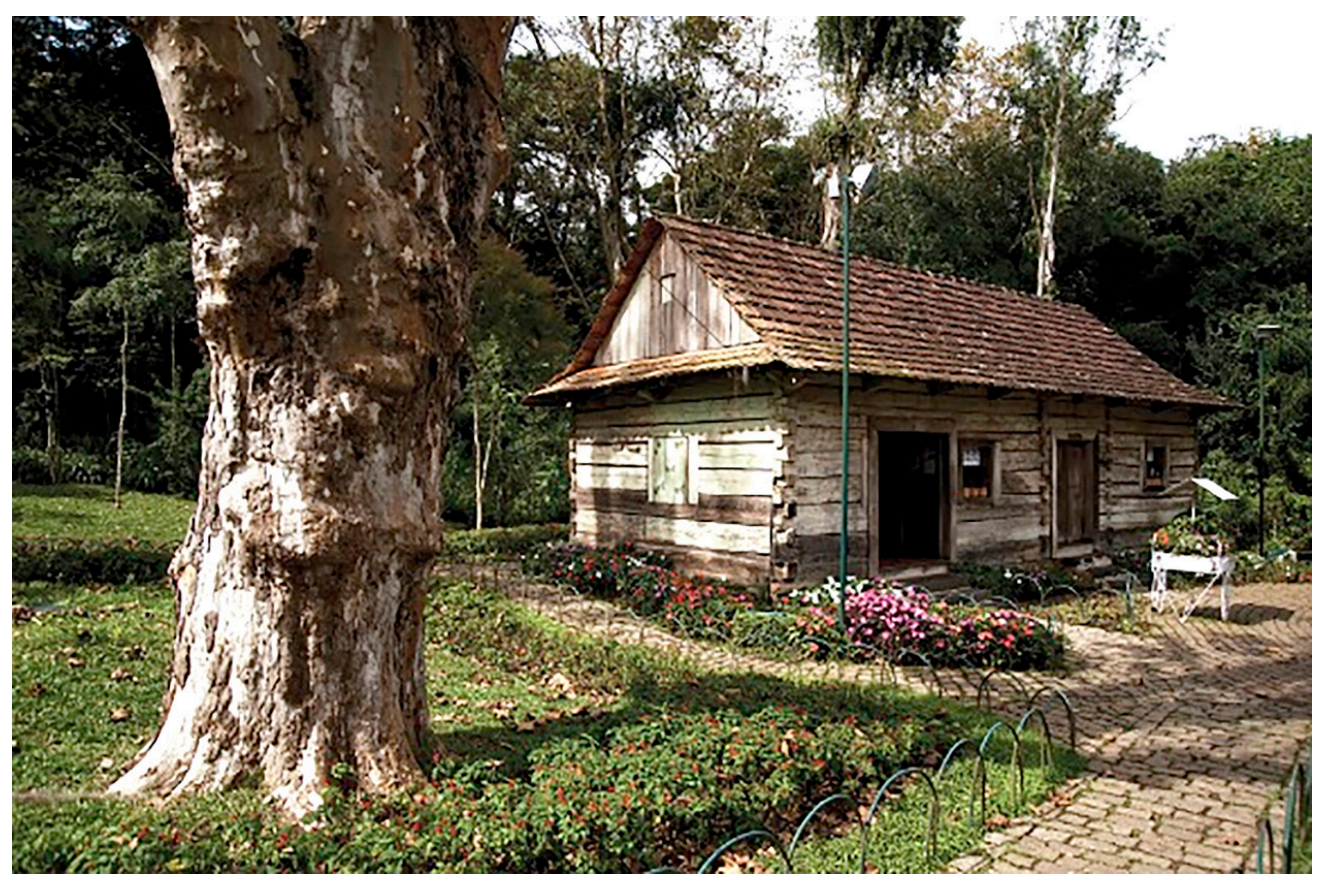

12. Disponível em <http:// nossaslinhas.blogspot.com. br/2011/05/o-bosque-que-tambem-sedia-o-memorial-da.html>. Acesso em: 6 nov. 2016.

13. Disponível em <http:// curitibaparanaocuritibanos. blogspot.com.br/2011/05/ bosque-do-papa-joao-paulo-ii.html>. Acesso em: 6 nov. 2016.

Figura 4 - Loja de artesanato e espaço administrativo - MIP. Fonte: Bosque do Papa / Memorial da Imigração Polonesa. Linhas. 25 maio $2011^{12}$

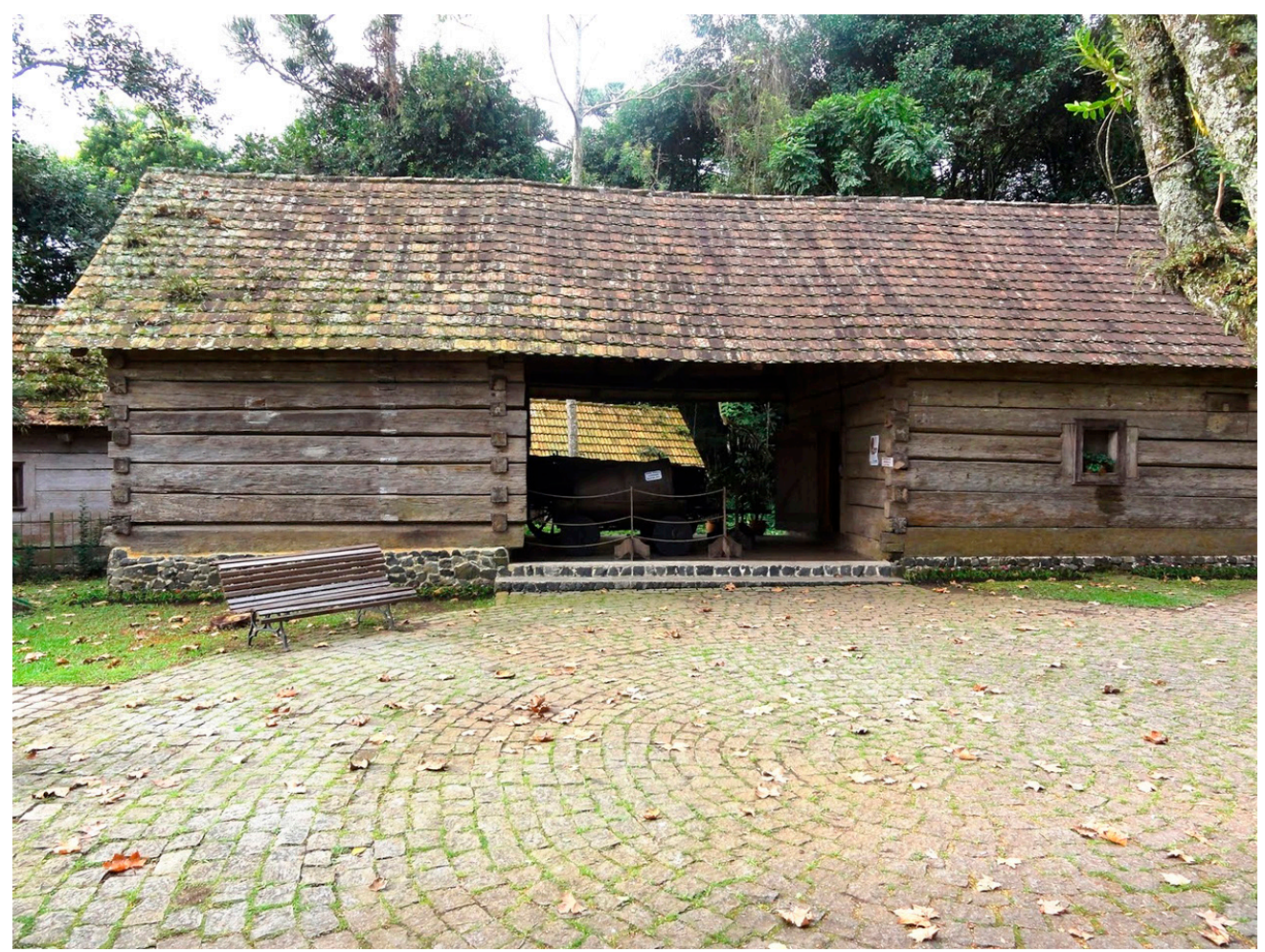

Figura 5 - Antigo Paiol do século XIX - MIP. Fonte: Curitiba para não curitibanos $^{13}$ 
14. Abreu (2007).

15. Abreu (2007).

16. Poulot (2013); Figueiredo; Vidal (2005); Chagas (2009), entre outros.

17. Winberry (1974, p. 59).
Os temas abordados nas exposições que acontecem na casa de eventos costumam acompanhar o calendário comemorativo da comunidade polonesa, de modo a divulgar e valorizar os aspectos culturais dos imigrantes poloneses. Entre tais temas, estão Natal, Páscoa, data da padroeira da Polônia ou o aniversário da beatificação do papa João Paulo II.

O Memorial de Imigração Polonesa oferece, ainda, ciclovia, parque infantil, sanitários e estacionamento, apresentando uma infraestrutura de parque público de acordo com as demandas de modernização urbana de Curitiba.

Como imigrante polonesa, a senhora Danuta Lisicki de Abreu, representante da Central da Comunidade Brasileiro-Polonesa no Brasil - Braspol, ao falar sobre si mesma, traz à tona memórias de grandes dificuldades pelas quais ela e sua família passaram durante a Segunda Guerra Mundial, antes de vir para - Brasil. Memórias de quando, ainda criança, sentiv a morte de perto:

[...] não se tinha alimento, era fome! De fato as dificuldades eram muito grandes, [...] houve um bombardeio e nossa casa foi em parte destruída [...], tinha roubo, tinha morte, [...] você não sabe o que te espera no dia seguinte $[\ldots]$ cada dia era diferente: bombas, minas [... $]^{14}$

Apesar de possuílas muito vivas, não é esse tipo de memória da Polônia em Guerra que a senhora Danuta e o MIP querem mostrar. Segundo a idealizadora e coordenadora do Memorial, ele foi criado para ser um lugar que traga paz e união entre os povos. ${ }^{15}$ Assim como uma grande parte dos museus brasileiros, o MIP surge como o guardião de memórias boas, daquilo que se quer preservar. ${ }^{16} \mathrm{Em}$ nenhum espaço do MIP, aparecem vestígios do sofrimento pelo qual os imigrantes passaram antes, durante ou depois de deixarem suas terras natais, como os traumas citados pela organizadora e coordenadora do MIP em sua entrevista. Nesse memorial, as memórias traumáticas não estão presentes.

\section{O processo de criação do Memorial da Imigração Polonesa}

A área onde se situa o Memorial da Imigração Polonesa e o Bosque João Paulo II foi desapropriada em 1977, por questões de controle de enchente do rio Belém. De forma gradativa, sete casas centenárias construídas com troncos de madeira foram transferidas, principalmente da Colônia Polonesa de Tomás Coelho, em Araucária, na região metropolitana de Curitiba, para o parque, e implantadas até obter a configuração atual do Memorial.

A particularidade das casas transplantadas para o MIP, além de sua origem, está na sua edificação a partir de troncos de pinheiros encaixados, sem o uso de pregos ou parafusos de qualquer natureza, técnica construtiva atribuída aos imigrantes poloneses e que pode ser encontrada em diferentes partes do mundo - Finlândia, Polônia, Checoslováquia, sul da Alemanha e sudoeste da França, assim como também na Rússia, Manchúria e Japão. ${ }^{17}$ 
Sobre o processo de transferência das casas provenientes da colônia de imigrantes para o Bosque João Paulo II, Neda Doustdar ${ }^{18}$ salienta que 0 "programa de construção de barragens para o aproveitamento dos rios e mananciais da região metropolitana" o qual envolveu "a construção da Barragem do Passaúna" e a desapropriação de $10 \mathrm{~km}^{2}$ de terras, incluiu grande parte da Colônia Tomás Coelho. Embora a justificativa para essa desapropriação passasse pelo discurso de uma política de valorização do patrimônio cultural, que procurava proteger as casas que seriam inundadas por ocasião do enchimento do reservatório do Passaúna, ${ }^{19}$ houve, por outro lado, grande polêmica com relação à situação dos desapropriados.

A colônia Tomás Coelho caracterizava-se por estar envolvida com o mercado de excedentes agrícolas para o abastecimento da região de Curitiba (Figura 6), mas cuja produção "perpetua[va]-se nos moldes ancestrais com resistências acirradas ou esparsas às inovações tecnológicas". ${ }^{20}$

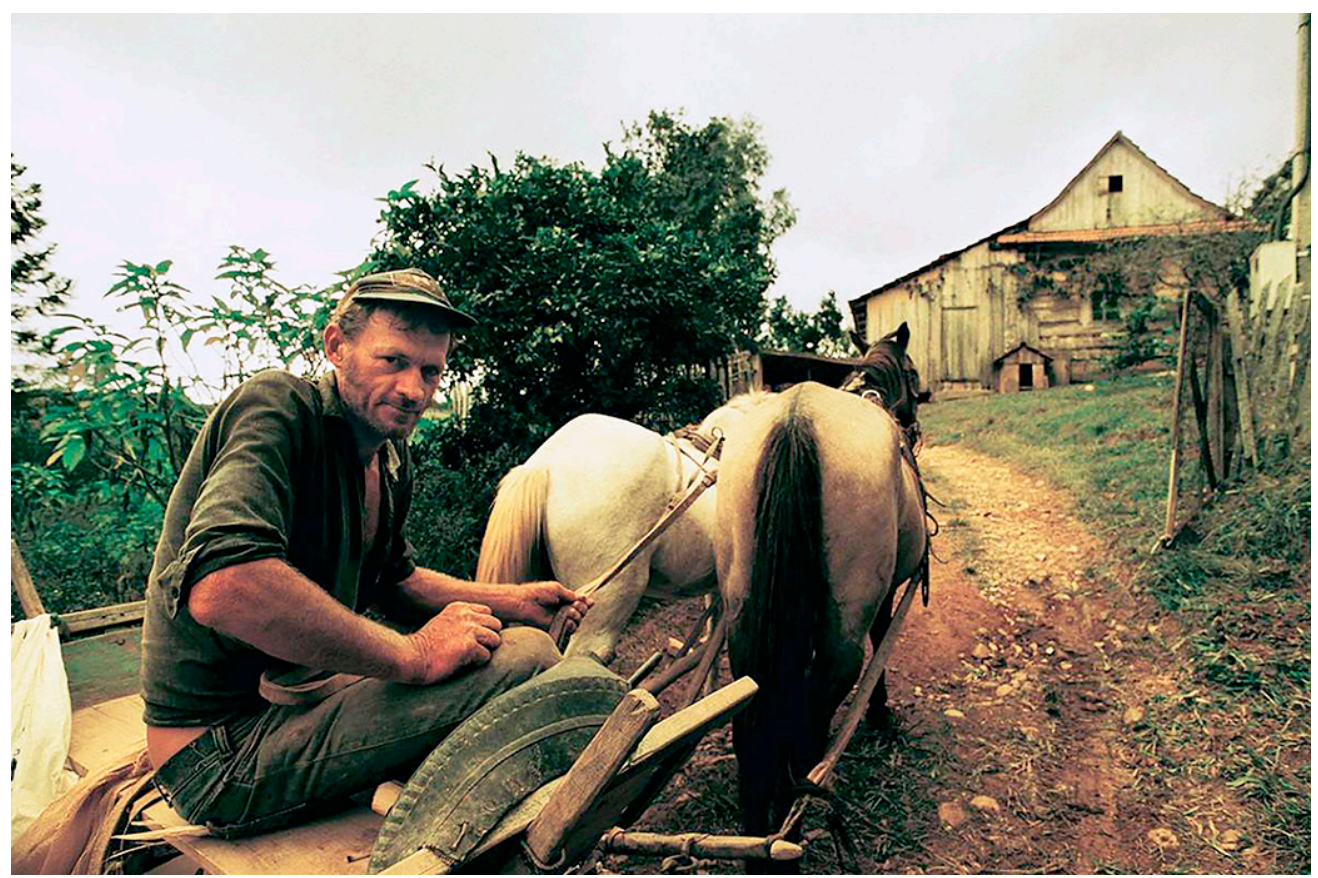

Figura 6 - Sr. Felix Dudek († 2003), bisneto de imigrantes, agricultor. Colônia Tomás Coelho, 1986. Fonte: João Urban. ${ }^{21}$

A desapropriação da colônia de imigrantes poloneses trouxe questionamentos sobre os sentidos da manutenção das referências culturais daquele grupo. Preservar o material, as casas, transformando-as em objetos de contemplação, destituindo-as de suas funções básicas - a moradia, por exemplo - e transferindo-as para um parque parece ir ao encontro do que discute o cientista social Henry Pierre Jeudy quando afirma que "[...] com frequência, o tratamento e a salvaguarda dos patrimônios orienta-se para um ideal de
18. Doustdar (1990, p. 1).

19. "A iniciativa de transplantar essas casas foi a solução encontrada pela prefeitura diante do risco de desaparecimento que corriam." PARANÁ (2006, p. 170).

20. Gil Filho (1994, p. 6).

21. Urban (2004, p. 128) 
22. Jeudy (1990, p. 3).

23. Maranhão. Folba de Londrina, 24 abr. 1985.

24. Jornal O Estado, p. 12, 1 fev. 1987.

25. Jeudy (1990).

26. Jeudy (1990, p. 2). memória 'rósea'. Os conflitos e os esquecimentos, os erros e os acidentes acabam sendo excluídos [...]". ${ }^{22}$

O descolamento da cultura material da questão da imaterialidade ali existente é refletido na entrevista de uma bisneta de poloneses, Lídia Lucaski, à jornalista Marlene Maranhão, do jornal Folha de Londrina, na ocasião do enchimento da barragem:

O lago, formado pela barragem, vai separar as terras, vão chegar outras pessoas e aquela unidade, amizade e entendimento acabará. Será muito difícil deixar casas que já têm mais de 100 anos e mudar-se para outro local, viver entre pessoas desconhecidas, que não falam o polonês, não entendem as tradições. Para os mais velhos - existem pessoas de mais de 90 anos - isso será fatal. Elas jamais se acostumarão a rezar em outra igreja, conviver com outras pessoas que não falam o polonês, mesmo por que, os mais idosos, mal falam o português. ${ }^{23}$

Com a manchete "Tomás Coelho vê o seu final com a chegada das águas", o Jornal do Estado, na edição de $1^{\circ}$ de fevereiro de 1987, mostrava a situação deprimente na qual se encontrava a população da colônia polonesa. "Para surpresa dos moradores do local, o desvio do rio foi antecipado [...] a situação no local é crítica, pois muitas famílias continuam morando ali e a água já está entrando nas residências." ${ }^{24}$ Com a imagem de uma residente na Colônia Tomás Coelho (Figura 7), o jornal ilustrava, na primeira página, a situação dos moradores já com a água em suas portas. A imagem mostra um modo de vida diverso e distante daquele mostrado no parque atualmente.

Ao transferir alguns exemplares de edificações de troncos da centenária colônia Tomás Coelho para um equipamento urbano situado numa área nobre da cidade, é possível lembrar a fala de Jeudy ${ }^{25}$ quando assinala a importância e a complexidade no trato com o patrimônio, no que diz respeito a pensá-lo a partir dos sujeitos,

[...] as palavras "patrimônio", "memória coletiva" ou "identidade cultural" perderam seu poder conceitual, tornando-se expressões vagas que acabam designando o próprio esvaziamento do seu sentido. Elas aparecem como "palavras de ordem" para programas sócio culturais cada vez mais repetitivos e equivalentes entre si. Mas a mobilização social que presumivelmente elas ocasionariam continua a se ampliar: nas regiões de todos os países do mundo, a busca das identidades culturais acaba motivando e dinamizando as práticas e políticas de conservação. [...] Desde então, conservar não quer dizer preservar ou salvaguardar, mas primeiramente restituir, reabilitar ou reapropriar-se. [...] Em seus próprios territórios, os grupos sofreriam com o desaparecimento dos seus referenciais culturais. Daí tal consenso em torno de uma reprodução ativa das imagens da cultura. Ao invés de serem inerentes as materialidades, as representações das diferentes culturas apresentam-se como objetos a serem percebidos, lidos e estudados. A cultura não se encontra mais na cabeça das pessoas, mas diante delas, composta de um número enorme de signos a serem descobertos e interpretados, ou ainda, revividos como a expressão de uma tradição incontestável. A necessidade da cultura traduz-se por uma "objetalização" das culturas. ${ }^{26}$ 


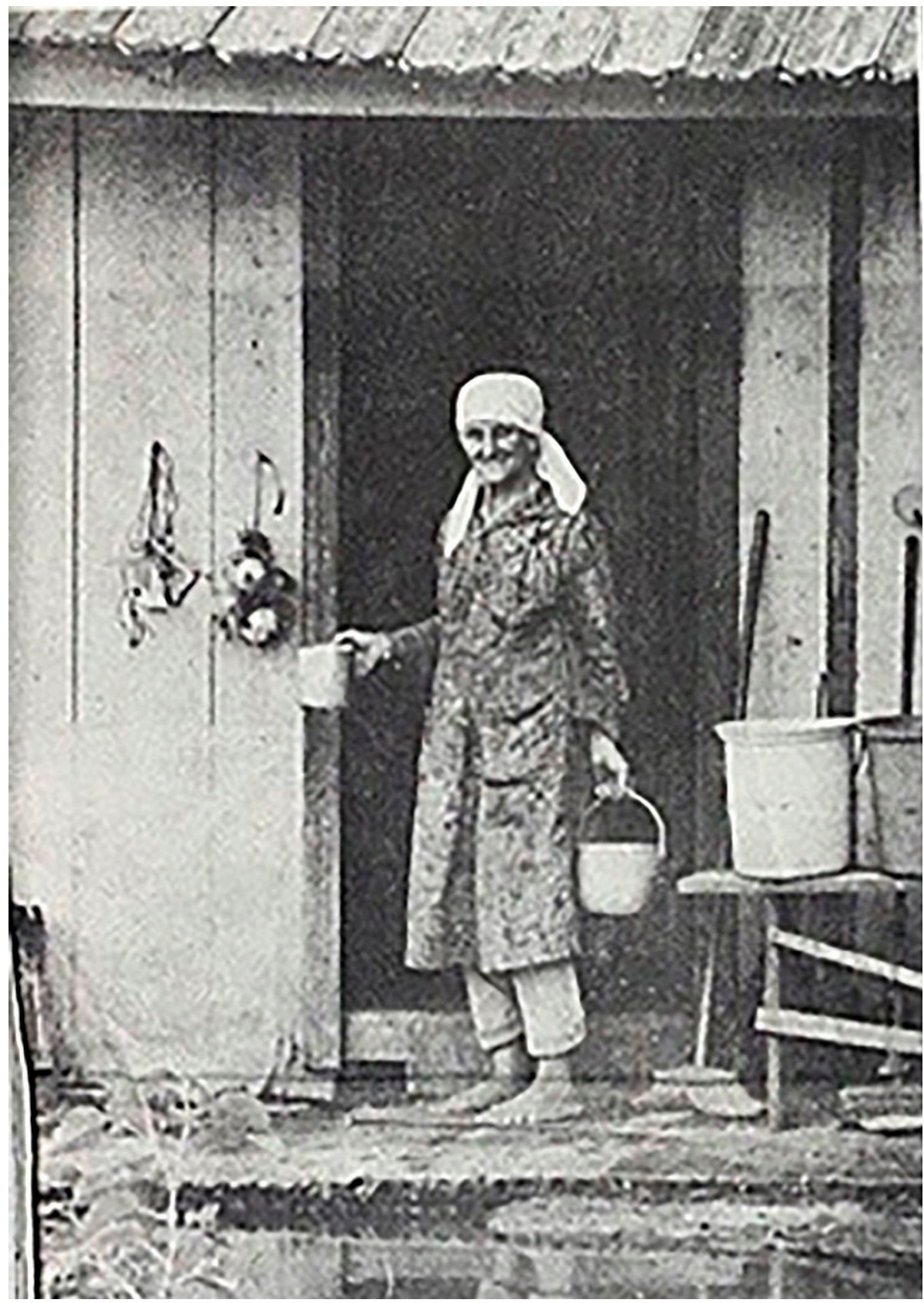

27. Jeudy (1990)

Figura 7 - Moradora de uma das casas inundadas na Colônia Tomás Coelho, 1987. Fonte: Jornal do Estado. Curitiba, p. 1, 1 fev. 1987

Nesses termos, Jeudy ${ }^{27}$ nos oferece uma interessante reflexão a respeito das representações das diferentes culturas ao acreditar na sua constante produção e transformação pelos sujeitos, em que patrimônio e memória seriam como partes de um conjunto na constituição das coletividades. $\bigcirc$ autor salienta que as políticas de preservação se esforçam em mostrar a materialidade da cultura, sem considerar 
28. Jeudy (1990).

29. Fundação Oswaldo Cruz (2013, p. 7).

30. Jeudy (1990).

31. Geissler (2004, p. 214).

32. Burke (2000, p. 73).

33. Garcia (1995, p. 1.134).

34. Garcia (1995, p. 1.134). sua dinâmica e sua constante transformação. Sendo assim, o patrimônio não se reduz à estocagem, à materialização e preservação. Jeudy ${ }^{28}$ identifica o conceito de conservação na forma de proteção aos recursos patrimoniais, das manifestações culturais, de forma a garantir a sustentabilidade de sua existência para as gerações futuras e não o de preservação. $\bigcirc$ conceito de preservação sugere a permanência em termos de materialidade, com a aplicação de "medidas e ações definidas com - objetivo de salvaguardar os bens culturais e garantir sua integridade e acessibilidade para as gerações presentes e futuras". ${ }^{29}$ A partir da análise desses dois conceitos, o de conservação e o de preservação, pode-se perceber os delineamentos das políticas e as ideologias aplicadas nos relacionamentos com o patrimônio e a sociedade.

Jeudy ${ }^{30}$ revela que, na maioria das vezes, quando o poder público direciona seus esforços para as questões do patrimônio, não considera a importância da efetiva relação do patrimônio com a memória e com a experiência das coletividades como produtoras do patrimônio, haja vista percebê-las somente como consumidoras. Relativamente às dinâmicas culturais, o patrimônio encontra-se em constante movimento e não se reduz a simples transferência de conhecimento, mas às apropriações culturais coletivas.

Como exemplo da arbitrariedade do poder público em termos de seleção do patrimônio como produto de consumo, tem-se também a área onde foi implantado o Bosque João Paulo II, onde se encontra o MIP, que era originalmente ocupada por uma chácara do início do século XX, sendo que, em 1974, "iniciaram as obras de demolição da casa, matadouro, moinho e remoção do parreiral", ${ }^{31}$ pertencente ao antigo proprietário. Apesar de retratar um modo de vida dos primeiros habitantes de Curitiba, essa ação também evidencia um processo de seleção de qual memória deveria ser preservada nas práticas do poder público da cultura.

Ao substituir um tipo de ocupação - a chácara - por outro - casas de tronco polonesas -, retiradas de seu lugar de origem e convenientemente transformadas em um memorial, evidencia-se qual a história que se desejava preservar e qual a cidade que se queria ter. Essa seleção leva à reflexão sobre a fala do historiador Peter Burke quando afirma que "as memórias são maleáveis, e é necessário compreender como são concretizadas, e por quem, assim como os limites dessa maleabilidade". ${ }^{32}$

A implantação do Bosque do Papa procurava responder, por meio da criação de uma área ambiental e de um parque étnico, a base de city marketing que estava sendo estabelecida na cidade e que utilizava, naquele período, a temática étnica com o slogan Curitiba de todas as gentes. De acordo com a arquiteta e urbanista Fernanda Sánchez Garcia, a política de city marketing tem como foco a promoção da cidade "no sentido de atração de atividades comerciais, de serviços e investimentos, além da promoção crescente de um turismo nitidamente urbanístico". ${ }^{33}$ Essa política tem como estratégia a construção da imagem da cidade, mesmo que isso tenha forte impacto social em suas ações. ${ }^{34}$ 
A respeito da administração da cidade de Curitiba, cabe salientar que a sucessão de mandatos exercidos por Jaime Lerner (1971-1975, 1979-1983 e 1988-1992) permitiu a continuidade de um projeto de remodelação da cidade, ${ }^{35}$ que teve prosseguimento na gestão de Saul Raiz (1975-1979). Oliveira afirma que a terceira administração de Jaime Lerner (1988-1992),

[...] optou por uma substancial mudança de enfoque que, relegando ao segundo plano os discursos e as práticas afetas ao planejamento urbano, enfatizou as realizações de ordem estética e uma política de caráter setorial: aquela voltada para o meio ambiente. Dificilmente se poderia exagerar o impacto que ambas causaram nacional e internacionalmente. ${ }^{36}$

Na gestão subsequente, do prefeito Rafael Greca (1993 - 1996), foi intensificada a implantação de outros memoriais étnicos, como o Memorial da Cultura Japonesa (1993 - Praça do Japão), o Memorial Ucraniano (1994 Parque Tingui), o Memorial da Língua Portuguesa (1994), o Memorial de Imigração Alemã (1 996), o Memorial da Imigração Árabe 1996 - Praça Gibran Khalil Gibran) e o Memorial de Imigração Italiana ( 1996 - Bosque São Cristóvão). Esses locais serviam e ainda servem como locais de festas folclóricas e religiosas, pontos de encontro de grupos de descendentes de imigrantes e para uso da população em geral.

Administrativamente, no município, o Memorial de Imigração Polonesa é vinculado à Fundação Cultural de Curitiba - FCC, por meio da Diretoria do Patrimônio Cultural. Esta, por sua vez, possui a coordenação dos dois únicos memoriais geridos pelo poder municipal: o Memorial de Imigração Polonesa localizado no Bosque João Paulo II, objeto deste artigo, e o Memorial de Imigração Ucraniana - localizado no Parque Tingui. Esses dois Memoriais possuem em comum o fato de estarem localizados em parques, possuírem uma capela e sua gestão estar vinculada a associações étnicas.

Os demais memoriais, apesar de também terem sido criados pela prefeitura, foram repassados administrativamente para a Secretaria Municipal de Educação, com a justificativa de conterem bibliotecas. A Secretaria de Educação se encarrega da promoção de ações culturais desenvolvidas nesses memoriais, considerados espaços de leitura, juntamente com as associações étnicas.

Na gestão municipal, as unidades museológicas estão voltadas para as artes visuais, como o Museu Municipal de Arte, Museu da Fotografia, Museu da Gravura e Museu de Arte Sacra e, por esse motivo, são vinculadas à Diretoria de Artes Visuais e não à de Patrimônio Cultural. Efetivamente, o poder municipal não possui uma coordenação de museus ou mesmo um sistema municipal de museus ao qual o MIP poderia estar vinculado caso ele fosse considerado um museu pelo poder público.

No que concerne à dinâmica institucional do MIP, esta pode ser reconhecida, a princípio, pelo termo de cooperação efetuado entre a Fundação Cultural de Curitiba e a Missão Católica Polonesa do Brasil em 1987 e em vigência 
37. Fundação Cultural de Curitiba (1987, p. 2).

38. Pires (2015).

39. Pires (2015).

40. Garcia; Moura (1999, p. 108).

41. Geertz (2011, p. 83).

42. Huyssen (2000).

43. Garcia (2001, p. 40).

44. Garcia (2001, p. 28). até os dias de hoje. Esse documento visa à animação e manutenção do Bosque, com cláusulas que nos remetem às funções características de um museu, como:

[...]c) estabelecer critérios para a obtenção de acervo de bens móveis ou imóveis [...]; d) conservar e restaurar os bens culturais móveis e imóveis; k) manter serviço, com o apoio da Missão Católica, de atendimento ao público. ${ }^{37}$

Um dos idealizadores do memorial, arquiteto Sérgio Pires, ao comentar sobre a criação do MIP e a possibilidade de ele ser um museu, afirmou que ele "não é museu, isso talvez seja um erro. [...] você tem um museu ao ar livre, mas eu acho que você pensar numa estrutura administrativa de museus não!"38

Nota-se, na fala do idealizador do MIP, que ele estabelece uma clara diferença entre "Museu" e "Museu ao ar livre" e a utilização deste último conceito como sinônimo de memorial, ou seja, como algo que não necessita das mesmas preocupações atribuídas a um museu no stricto sensu da palavra. Por outro lado, a proposta inicial de criação do MIP, por parte do Instituto de Pesquisa e Planejamento Urbano de Curitiba - IPPUC, segundo o entrevistado, tivera um contorno urbanístico com a instalação de um equipamento com fins de lazer de temática étnica. ${ }^{39}$

Recuperando a discussão a respeito da proposta de implantação de memoriais, essa iniciativa reforçava a imagem de Curitiba como uma cidade de primeiro mundo, com uma população de origem europeia.

A política cultural oficial dos anos 90 em Curitiba recompõe as várias culturas que participaram do movimento de colonização da região, através de memoriais étnicos na arquitetura urbana associados a novos parques como o Tingui, dos ucranianos, o "Bosque Alemão", ou o "Bosque do Papa", dos poloneses. Esses espaços de celebração das etnias e da natureza exaltam, ao mesmo tempo, o próprio projeto de cidade. ${ }^{40}$

A representação de Curitiba como cidade de população de origem europeia, criada pela gestão municipal, decorreu de uma operacionalização de city marketing, a fim de implantar uma determinada imagem da cidade, como citado anteriormente. "Como as formas sociais, as formas simbólicas podem servir a múltiplos propósitos", ${ }^{41}$ como o de satisfazer o desejo de memória ${ }^{42}$ de alguns e o de aumentar a atratividade do turismo na cidade e de investidores internacionais, conjugados, ainda, aos interesses do mercado imobiliário, fazendo com que o poder público intensificasse novos investimentos em áreas nobres de Curitiba.

No jogo do campo simbólico, não é apenas o poder do dinheiro que vale, "mas o poder que a riqueza exerce sobre os espíritos, sobre as mentes. É algo que amplia a definição dos campos de poder, diferentemente do poder político ou econômico". ${ }^{43} \bigcirc$ sentido dessas colocações no campo simbólico, manifestadas por meio das ações de city marketing, "contribui para o exercício da violência, especialmente em sua forma simbólica, pelas vias da comunicação e do conhecimento, violência nem sempre percebida por suas próprias vítimas". ${ }^{4}$ 
A cidade se faz como um espetáculo, em constante renovação. É concebida dia a dia, reduzida a slogan e bordões superficiais de uma imagem de cidade. Essa estratégia de city marketing pelos gestores da cidade enraíza novos hábitos na população, como também provoca um custo social, como a discriminação das parcelas da população não representadas pelos memoriais, tais quais a negra, a indígena e a migrante, como no caso da cidade de Curitiba. "Deste modo, o espaço toma forma também através de representações e imagens adequadas, o que explica a importância que vem adquirindo o city marketing como instrumento das políticas urbanas". ${ }^{45}$

No estudo comparativo entre as cidades de Curitiba no Brasil e Barcelona na Espanha, Rovira e Garcia ${ }^{46}$ salientam que as políticas de desenvolvimento urbano e a produção das imagens pelo poder público podem ser caracterizadas pelo uso frequente dos meios de comunicação, como ações de apoio aos governos na construção do modelo de city marketing.

Los medios de comunicación e información que, en los casos analizados, han sido intensamente utilizados como vehículos constructores de determinadas lecturas de la ciudad, intervienen decisivamente en la creación de valores culturales y de representaciones sociales que, a su vez, promueven determinados comportamientos y formas de utilización de los espacios públicos. ${ }^{47}$

Na análise das autoras, o uso de city marketing pode ser considerado como uma ferramenta para a construção da imagem da cidade, criando representações sociais da cidade pela população de maneira geral, influenciando comportamentos e as formas de viver o espaço público.

Em complemento à visão da cidade espetáculo, de Jeudy ${ }^{48}$ e Garcia, ${ }^{49}$ Ulpiano Bezerra de Meneses ${ }^{50}$ propõe a possibilidade de pensar a cidade como artefato, produto e vetor das relações sociais, ou seja, "a cidade é um artefato, coisa feita, fabricada pelo homem, segmento do universo material socialmente apropriado [...] todo o artefato é, ao mesmo tempo, produto e vetor das relações sociais". 51

De fato, a cidade-artefato pode ser vista como algo feito e fabricado pelo homem, em ação e desconstrução, pensada pelos seus habitantes. Esta reflexão também é desenvolvida pelo historiador Moacir Freitas, em que sinaliza um sentimento de pertencimento dos seus habitantes,

Cidade-Artefato é a cidade entendida como patrimônio, que não corresponde mais à imagem estática, "pasteurizada", "asséptica" e "chapada" da fotografia postal, ou seja, da imagem produzida para o consumo, como cidade que prescinde da experiência. A essa representação quase abstrata se contrapõe a imagem dinâmica do seu viver cotidiano. ${ }^{52}$

Na dialogicidade entre cidade-espetáculo e cidade-artefato, pode-se entender que o MIP representa parte de cada processo. Tanto inserido na construção da imagem urbana na estratégia de city marketing do poder público, como também no processo de apropriação de uso como patrimônio cultural.
45. Sanchez (2001, p. 32).

46. Garcia; Rovira (1999).

47. Garcia; Rovira (1999, p. 42).

48. Jeudy (2005).

49. Garcia (1999).

50. Meneses (1985).

51. Meneses (1985, p. 199).

52. Freitas (2014, p. 4). 
53. Gonçalves (2005, p. 227).

54. Gonçalves (2005).

55. Williams (2007, p. 8).

56. Lennon; Foley (2000, p. 23). Apud Williams (2007, p. 6).

Na abordagem de cidade-artefato, a apropriação do patrimônio por parte dos seus habitantes passa a ser significativa, considerando que "o sentido fundamental dos 'patrimônios' consiste talvez em sua natureza total e em sua função eminentemente mediadora". ${ }^{53}$

Segundo Gonçalves ${ }^{54}$ o patrimônio é fator de mediação e comunicação de determinado grupo e este compartilha e se apropria desse significado, inclusive gerando outras identidades. Assim, O MIP, no contexto urbano, pode ser percebido como um campo de forças, cenário e produto das representações sociais de seus habitantes. Seria este o papel de um memorial no espaço urbano? Para aprofundar essa discussão, propõe-se analisar a criação de outros memoriais tanto no Brasil como fora dele.

Reflexões sobre o conceito de Memorial

Em estudo abrangente sobre Museus Memoriais, "Memorial Museums: The Global Rush to Commemorate Atrocities", o professor da Universidade de Nova York, Dr. Paul Harvey Williams, ${ }^{55}$ considera que os Memoriais na atualidade se apresentam como um novo lugar de memória, especialmente destinados a lembrar grandes tragédias, momentos traumáticos da humanidade e, por isso, são imbuídos de uma determinada interpretação histórica que lhes proporciona um papel social importante.

Os primeiros memoriais criados nos anos 50 estavam associados ao tema dos genocídios de vítimas de guerra: o Museu da Paz, inaugurado em 1955, na cidade de Hiroshima no Japão, construído no local onde caiu a bomba atômica na segunda guerra mundial, e o Yad Vashem, do ano de 1953, em Jerusalém, em Israel, um dos principais centros para a guarda da memória sobre o Holocausto.

Lennon e Foley trabalharam os memoriais de guerra como partes do que chamaram de "Dark tourism" e explicaram que "while the Holocaust is tied to the Second World War, its obvious antinomy to 'conventional warfare' has meant that its memorialization has required considerable departures in form and meaning". ${ }^{56} \mathrm{~A}$ partir dessa colocação, Williams esclarece que, na Segunda Guerra Mundial, principalmente pensando em relação ao Holocausto e à bomba nuclear, houve tragédias humanas com proporções inéditas, cujas vítimas eram civis e não soldados em combate, o que caracterizou uma diferenciação em relação às guerras convencionais e também à necessidade de uma nova forma de memorialização, daí a criação dos memoriais.

O autor segue em sua tentativa de delimitar o campo de conhecimento a respeito de memoriais, tema central de seu trabalho, apresentando, em linhas gerais, as principais características distintivas a respeito de monumento, museu memorial e sítio memorial, 
A monument is a sculpture, structure or physical market designed to memorialize. A museum, as we know, is an institution devoted to the acquisition, conservation, study, exhibition, and educational interpretation of objects with scientific, historical or artistic value. I use the term memorial museum to identify a specific kind of museum dedicated to a historic event commemorating mass suffering of some kind. A final term, the memorial site, is used to describe physical locations that serve a commemorative function, but are not necessarily dominated by a built structure. ${ }^{57}$

Williams, ${ }^{58}$ ao definir um conjunto de termos referentes a monumentos, museus e museus memoriais, busca delimitar o campo de trabalho quanto às especificidades e características de cada forma de memorialização. $\bigcirc$ autor acrescenta, ainda, que os memoriais existentes em todas as partes do mundo em que ocorreram conflitos armados foram construídos em vários períodos, com estruturas políticas e culturais diferenciadas em seus discursos.

No território europeu, apenas no final do século XX, houve um movimento voltado à patrimonialização de espaços de memória, ligados à II Guerra Mundial e ao Holocausto. Locais como antigos campos de concentração, não só na Alemanha, mas em outras partes da Europa, têm sido musealizados. Como exemplos, têm-se os memoriais localizados nos antigos campos de concentração, como Sachsenhausen-Berlim (Alemanha), Mauthausen (Áustria) ou Auschwitz (Polônia). Desenvolvidos a partir da criação de espaços musealizados, esses memoriais se propõem a refletir sobre a trágica história do século XX na Europa, contribuindo assim para a consolidação de uma sociedade que garanta a liberdade e os direitos humanos.

Muitos desses espaços estão preservados pela Organização das Nações Unidas para a Educação, a Ciência e a Cultura - UNESCO, como o sítio de Auschwitz-Birkenau, campo de concentração situado na Polônia, na lista do Patrimônio Mundial desde 1979, como símbolo da crueldade do homem para com seu semelhante. No caso deste sítio, a proteção do patrimônio histórico abarca o conjunto de suas edificações, e o entorno e está inscrito na forma de paisagem cultural. Conforme o museólogo catalão Jordi Guixé i Coromines, esses espaços de patrimonialização abrangem "desde la arquitectura hasta el medio. Espacios memoriales, itinerarios de memoria y otros vestigios han encontrado en este espacio cultural su fórmula dinamizadora, sus recursos y su aproximación al ciudadano". ${ }^{59}$

Comumente, lembrar tem o sentido de manter vivo algo que já aconteceu, para que seja lembrado também pelas futuras gerações ou para que não mais venha a ocorrer. Uma característica marcante da memória é que ela abrange tanto a lembrança como o esquecimento. Em relação ao sofrimento, segundo o antropólogo Joël Candau, ele "é sempre eletivo, um grupo pode fundar sua identidade sobre uma memória histórica alimentada de um passado prestigioso, mas ele se enraíza com frequência num 'lacrimatório' ou na memória do sofrimento compartilhado". 60
57. Williams (2007, p. 8). Um monumento é uma escultura, estrutura ou objeto físico concebido para memorizar algo. Um museu, como sabemos, é uma instituição dedicada à aquisição, conservação, estudo, exposição e interpretação educacional de objetos com valor científico, histórico ou artístico. Eu uso o termo Museu Memorial para identificar um tipo específico de museu dedicado a um evento histórico que comemora o sofrimento em massa de algum tipo. O termo final, o Sítio Memorial, é usado para descrever locais físicos utilizados com uma função comemorativa, mas não estão necessariamente dominados por uma estrutura construída (tradução livre).

58. Williams (2007, p. 8$)$.

59. Coromines (2008, p. 223).

60. Candau (2011, p. 151). 
61. Disponível em <https:// www.911 memorial.org/ exhibitions>. Acesso em: 5 ago. 2016

62. Obama (2014)
As grandes violações de direitos humanos levaram à construção de importantes projetos de memória do sofrimento. O Museu Memorial e o Memorial 11 de Setembro de New York - US (Figura 8) talvez possam ser os mais conhecidos por representarem um atentado relativamente recente, de grandes proporções, e que foi, em parte, televisionado para várias partes do mundo. Instalados onde antes estavam as torres gêmeas do Word Trade Center e abertos ao público em 2014, o Memorial, também chamado de Tribute Center, possui a função de homenagear os cerca de 3000 mortos no ataque terrorista de 11 de setembro de 2001, diferentemente do Museu, cujo papel é de explorar as implicações dos eventos de 11 de setembro, documentando o impacto de forma continuada.

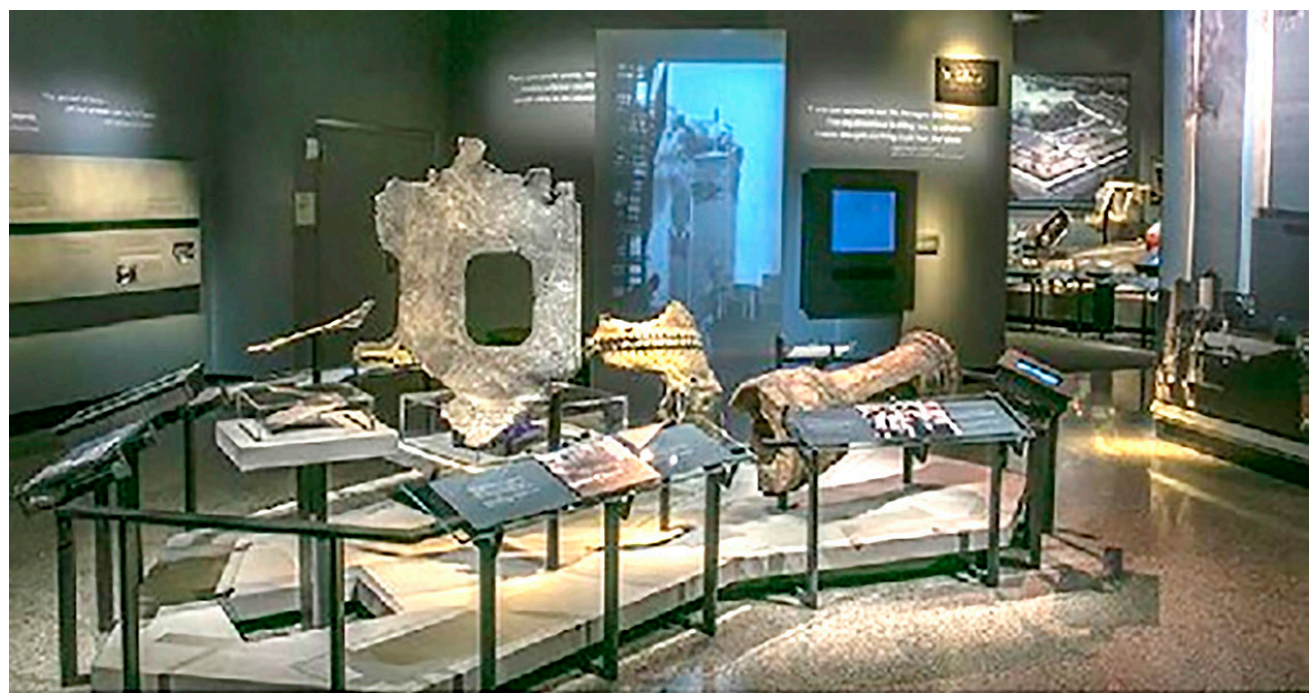

Figura 8: Museu Memorial 9/1 1 em NYC (US). Fonte: 9/1 1 Memorial. ${ }^{61}$

Em seu discurso inaugural do Museu Memorial 11 de setembro, publicado pela Casa Branca, o presidente Barack Obama salientou a preocupação pela continuidade da memória, para lembrar e refletir,

On behalf of Michelle and myself and the American people, it is an honor for us to join in your memories. To remember and to reflect. [... for bringing us to this day, for giving us this sacred place of healing and of hope. Here, at this memorial, this museum, we come together. [...] because no act of terror can match the strength or the character of our country. Like the great wall and bedrock that embrace us today, nothing can ever break us: nothing can chance who we are as Americans. ${ }^{62}$

Percebe-se, nesse discurso, a necessidade da construção de uma narrativa nacionalista, evidenciando-se temas como memória, honra, esperança e orgulho. De acordo com Violaine Morin, articulista do Jornal francês Le Figaro, "Mais deux polémique sen tourent l'ouverture du musée: la 
pédagogie autour de l'islam radical et du diihadisme et la construction d'um 'reposoir' pour les restes de victimes non-identifiés",63 temas que ficam nas entrelinhas do discurso do presidente americano. Nesse recorte, evidencia-se que os conteúdos da informação nesses memoriais passam, necessariamente, pelos vieses político, social e histórico.

De fato, o debate sobre os crimes de guerra, sobre o holocausto ou ataques terroristas passa a ter uma perspectiva diferenciada não só na escrita da história como também para os processos museológicos e de memória coletiva, abrindo o entendimento sobre o papel político das instituições de memória, no caso, museus e memoriais.

Muito mais que mostrar as histórias traumáticas, segundo Williams, ${ }^{64}$ os memoriais funcionam como lugares de sítio, construídos tanto por histórias oficiais como por histórias pessoais. $\bigcirc$ autor considera que, em termos de interpretação de conteúdo, os memoriais expressam algumas preocupações,

A memorial is seen to be, if not apolitical, at least safe in the refuge of history. This is largely because we recognize that honor will accrue to most people - no matter their actual worldly deeds - simply because honest evaluation of the dead is normally seen as disrespectful. A history museum, by contrast, is presumed to be concerned with interpretation, contextualization, and critique. The coalescing of the two suggest that there is an increasing desire to add both a moral framework to the narration of terrible historical events and more in-depth contextual explanations to commemorative acts. ${ }^{65}$

autor segue sua análise pontuando que o aumento do número de museus memoriais após a Segunda Guerra Mundial está correlacionado ao direcionamento das grandes narrativas e experiências autoritárias em museus nacionais. Ao invés de ser imerso em narrativas históricas prontas, os visitantes dos memoriais, ao contrário, são solicitados a ter "experiences that are sensory and emotional rather than visual impassive". $60 \bigcirc$ autor considera que a experiência nesses espaços possa ser mais fluída, menos hierárquica e mais pessoal.

Os memoriais, ao representarem uma nova forma de memorializacão, propõem a sensibilização e o diálogo com o público em contraponto aos museus de história e suas formas de memória: "Between the ephemeral and the permanent, between dissolving personal memory and hardened official histories". ${ }^{67}$

Williams destaca as possibilidades de narrativas desses objetos em exposições de museus, que tanto podem ser respaldadas pelas palavras e pelos documentos que as acompanham, como também podem ter sua significação ampliada quando interpretadas pelos curadores ou pelo público visitante. "We understand that stories about the past are what give life to objects, rather than vice versa". 68

Os acervos de objetos dos memoriais são utilizados, geralmente, nas exposições como testemunhos subjetivos, na forma de itens pessoais, como sapatos, peças de vestuário e imagens, inseridos em cenários que concorrem para a ambientação da mensagem. Desse modo, ao dar voz aos objetos silenciosos, os
63. Morin (2014). Mais duas controvérsias em torno da abertura do museu: a pedagogia em torno do radicalismo do Islã e do jihadismo e a construção de um "repositório" para os restos mortais de vítimas não identificadas (tradução livre).

64. Williams (2007).

65. Williams (2007, p. 8).

66. Williams (2007, p. 3).

67. Williams (2007, p. 1).

68. Williams (2007, p. 49). 
69. Williams (2007, p. 31).

70. Paul Harvey Williams (2007, p. 167).

71. Barcellos (1999).

72. Barcellos (1999, p. 3).

73. Barcellos (1999, p. 11). visitantes são levados, muitas vezes, a refletir sobre momentos de grande sofrimento ou ligados à memória da morte, "the effect of for enclosing the life to which the museum attaches it by reducing it to its period of greatest suffering". ${ }^{69}$ Em geral, objetos de museu memorial são destinados a captar um momento da história coletiva, de forma que o objeto possa representar um evento traumático, um momento, e não uma pessoa individualmente.

No entanto, o autor adverte quanto ao controle da narrativa de um museu e o congelamento do significado do objeto que, muitas vezes, leva à sacralização da memória nacional ou à construção de mitos. "The language and themes used to construct what is a now sacred national memory has placed the event almost beyond dispute, allowing it to harden into myth" ${ }^{70}$

Inevitavelmente, os museus sofreram uma série de mudanças ao assimilarem a realidade em diferentes períodos e, com isso, assumiram posturas paradigmáticas distintas que viabilizaram o aparecimento de novas instituições e processos de musealização específicos, como no caso dos memoriais. Dessa maneira, os memoriais articulam a delicada relação entre a história oficial e a história dos sujeitos, na perspectiva de promover a discussão de temáticas que envolvam a sociedade contemporânea.

Os memoriais no Brasil

As reflexões apresentadas no item anterior deixam visível a necessidade de aprofundamento das discussões a respeito dos memoriais. Em termos de Brasil, há uma variedade ainda maior de realidades. $\bigcirc$ historiador Jorge Barcellos, ${ }^{71}$ ao procurar um conceito para os memoriais, analisa o perfil institucional de diversos memoriais, com a intenção de delimitar "seu objeto e campo de atuação, distinguindo-o de seus congêneres centro cultural e museu" ${ }^{72}$ Em sua análise, o autor propõe que os memoriais não possuam as mesmas atribuições de um museu,

○ eixo sobre o qual o trabalho de um memorial deve centrar sua organização é a memória do Estado ou da instituição a que se refere - o que os libera de se constituírem, como os demais museus [...] em função de determinados acervos, temas ou objetos. ${ }^{73}$

Percebe-se que, nessa análise, o autor direciona os trabalhos do memorial na organização das memórias do estado ou de instituições, sem a pretensão de possuírem as características institucionais de um museu.

No decorrer dos tempos, os museus sofreram uma série de mudanças que viabilizaram o aparecimento de novas instituições, como o caso dos memoriais, cuja pluralidade de temas e formatos ocorre de maneiras diferenciadas.

Na tentativa de categorizar os memoriais, o Conselho Internacional de Museus implantou em 2001 o Comitê Internacional de Museus Memoriais (IC-

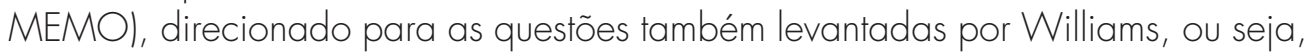
à preservação da memória de vítimas de crimes de estado. 
These institutions function as museums with a stock of original historical objects, which generally includes buildings, and work in all the classical fields of museum work (collecting, preserving, exhibiting, doing research, providing education). Their purpose is to commemorate the victims of state and socially determined, ideologically motivated crimes. They are frequently located at the original historical sites, or at places chosen by the victims of such crimes for the purpose of commemoration. They are conceived as memorials admonishing visitors to safeguard basic human rights. As these institutions co-operate with the victims and other contemporary witnesses, their work also takes on a psychosocial character. Their endeavours to convey information about historical events are morally grounded and aim to establish a definite relationship to the present, without abandoning a historical perspective. ${ }^{74}$

Conforme consulta no Cadastro Nacional de Museus, atualizado em 05/12/2015, do Instituto Brasileiro de Museus - IBRAM, existem 259 unidades museológicas no Brasil com o nome Memorial. Percebe-se que os memoriais elencados na publicação estão voltados para a preservação e difusão da memória, seja institucional, biográfica ou de uma cultura específica. Nesses locais, acontecem atividades culturais, educativas e técnicas. Constatou-se que, em termos de apresentação ao público, edificação, estrutura de pessoal e estrutura física, possuem grande diversidade, não apresentando uma uniformidade de perfil, como nos exemplos elencados nesta análise.

Alguns memoriais, além de acervo biográfico e temática voltada às atividades do homenageado, possuem, em suas instalações, mausoléus para a guarda dos restos mortais de figuras notáveis, como no caso do Memorial Juscelino Kubitschek (Figura 9), que contou com projeto arquitetônico de Oscar Niemeyer em Brasília - DF, o Memorial Nereu Ramos, na cidade de Lages - SC, ou o Memorial Marechal Mallet, voltado para a história militar e localizado no Quartel do $3^{\circ}$ Grupo de Artilharia em Santa Maria - RS.

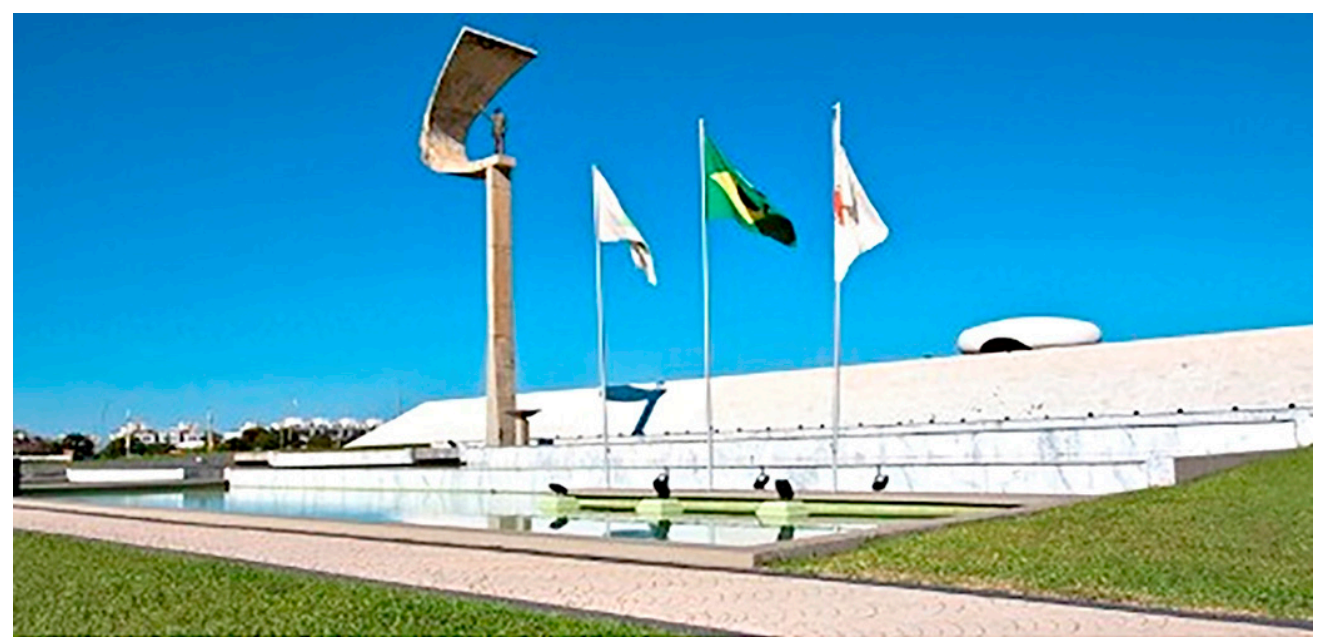

Figura 9 - Memorial Juscelino Kubitscheck em Brasília (DF). Fonte: Brasília reúne atrativos clássicos da arquitetura moderna. Memorial JK. Portal Brasil, 23/2/2015.75
74. ICOM/ICMEMO (2001, p. 1). Estas instituições possuem a função de museus com um acervo de objetos históricos originais, que inclui geralmente edifícios, e atuação em todos os campos clássicos de trabalho do museu (coleta, conservação, exibição, pesquisa, e ensino). Sua finalidade é homenagear as vítimas do estado e de determinados crimes, ideologicamente motivados. São frequentemente localizados nos locais históricos originais ou em locais escolhidos pelas vítimas de tais crimes para efeitos de celebração. Estão concebidos como memoriais advertindo visitantes para salvaguardar os direitos humanos básicos. Como estas instituições cooperam com as vítimas e outras testemunhas contemporâneas, seu trabalho também possui um caráter psicossocial. Seus esforços para transmitir informações sobre eventos históricos são moralmente fundamentados e possuem o objetivo de estabelecer uma relação definida para o presente, sem abandonar a perspectiva histórica (tradução livre).

75. Disponível em <http:// www.brasil.gov.br/turismo/2015/02/brasilia-reune-atrativos-classicos-da-arquitetura-moderna>. Acesso em: 30 maio 2016. 
76. Martins (2015, p. 10).

77. Disponível em <www. memorialdaresistenciasp. org.br>. Acesso em 30 jun 2016.
Nota-se que os memoriais brasileiros estão mais voltados a homenagear personagens ilustres do que a criação de lugares de memória coletiva com a função de testemunhar acontecimentos marcantes do passado.

O patrimônio cultural na forma de testemunhos de um passado de guerra ou mesmo de resistência ao estado democrático pode se apresentar como expressão da memória e da identidade de um grupo, de uma região ou de uma nação. Nesse viés, as instituições de memória como museus e memoriais possuem a capacidade de,

[...] afirmar certas identidades mas de propor reflexões humanistas e cosmopolitas sobre temas como a relação entre o passado, o presente e o futuro, a natureza do próprio patrimônio e para expor conflitos ou relações de poder desiguais e para "chegar a um acordo" com os grandes flagelos da Humanidade. ${ }^{76}$

Como exemplo de memorial voltado para a organização das memórias de estado ou de instituições, é possível citar o Memorial da Resistência de São Paulo (Figura 10), que trata da resistência e repressão política do Brasil República, com enfoque no regime militar. $\bigcirc$ Memorial da Resistência, localizado na antiga sede do Departamento Estadual de Ordem Política e Social de São Paulo - Deops/ $\mathrm{SP}$, segue o que a maioria dos museus de heranças difíceis, ou museus memoriais, como afirma Williams, tentou estabelecer: o vínculo com os locais em que a atrocidade ocorreu, procurando maior autenticidade.

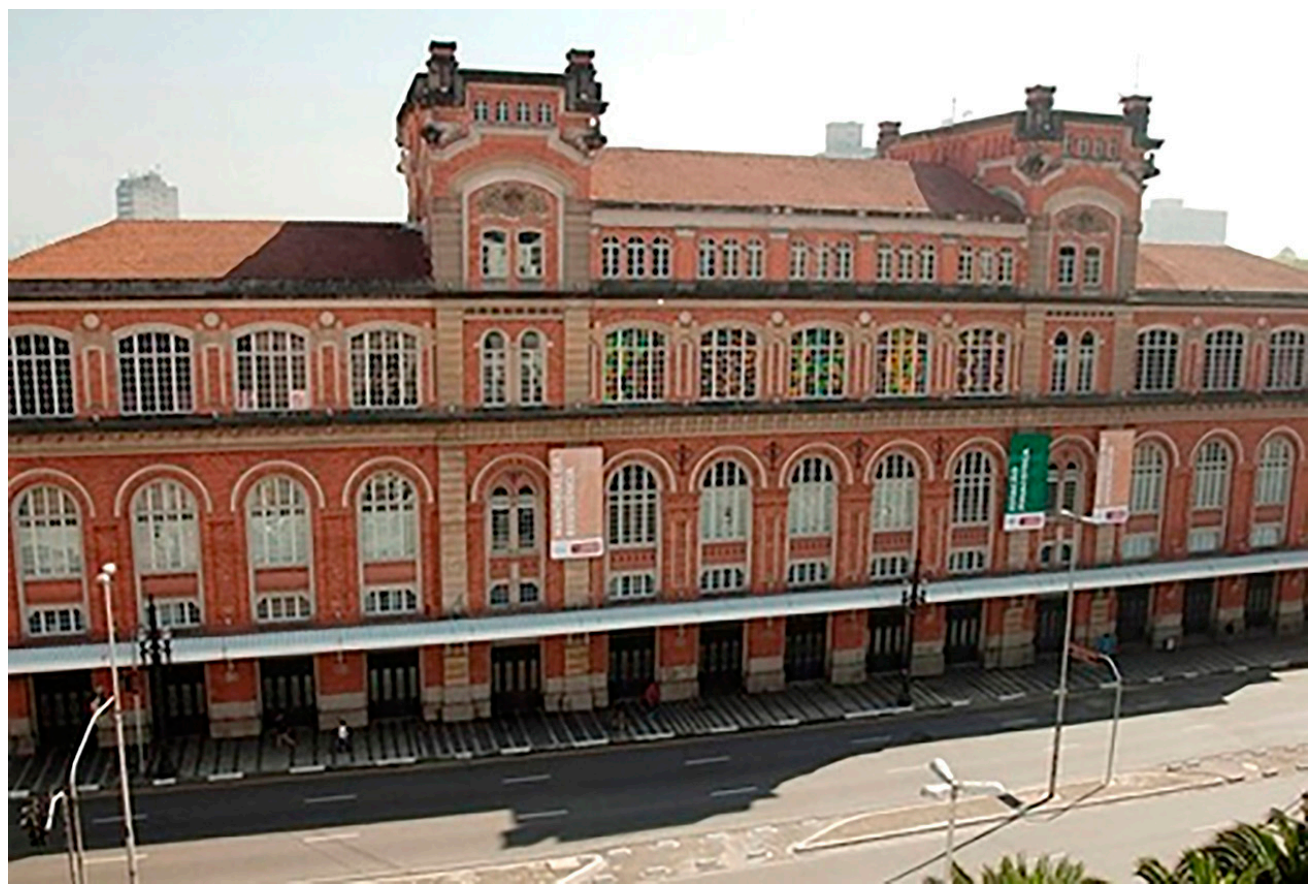

Figura 10 - Memorial da Resistência. São Paulo - SP. Fonte: Memorial da Resistência de São Paulo. Portal do Governo.77 
Como se pode observar, os memoriais, assim como os museus, podem ser concebidos com diversos perfis, sejam arquitetônicos, museográficos ou administrativos, mas, ao passarem por um processo de musealização, apresentam a possibilidade de uma leitura mais ampla. Jeudy, ao focalizar o papel das instituições museológicas no mundo social, afirma que elas "se apresentam como espaços de organização e de evocação das referências culturais que servem ao desenvolvimento do conhecimento". 78

Williams ${ }^{79}$ acredita que a criação de Memoriais como instituições de memória revolucionou a realidade dos museus históricos, na medida em que proporcionou novos processos de memorização que incluem diferentes interpretações históricas e crítica da realidade, ampliando a função social dos museus.

A tendência democratizante do museu, com novos processos de memorização e a ênfase na sua função social, teve destaque a partir da realização da Mesa Redonda de Santiago do Chile, em 1972, organizada pela UNESCO e com o apoio do ICOM. Nessa ocasião, a temática versou em torno do papel dos museus na América Latina, com ênfase nas questões de integração do museu à população local, patrimônio e meio ambiente, em substituição aos enfoques dos museus tradicionais em que público, coleção e edifício centravam as preocupações das instituições.

Século XX registrou importantes mudanças na trajetória dos museus, reconsiderando a diversidade dos espaços museológicos. Na mais recente definição de museu proposta pelo ICOM, percebe-se o reconhecimento de que os museus possuem inúmeras atribuições,

O museu é uma instituição permanente sem fins lucrativos, ao serviço da sociedade e do seu desenvolvimento, aberta ao público, que adquire, conserva, investiga, comunica e expõe o património material e imaterial da humanidade e do seu meio envolvente com fins de educação, estudo e deleite..$^{80}$

cenário museológico brasileiro é caracterizado atualmente por um novo modelo de gerenciamento, embasado por diretrizes e políticas públicas definidas em âmbito nacional que visam à preservação e divulgação do patrimônio. Um dos instrumentos do setor, o Estatuto de Museus (Lei n 11.904), implantado em 2009, contempla, em seu art. $1^{\circ}$, que são considerados museus as "instituições e os processos museológicos voltados para o trabalho com o patrimônio cultural e o território visando ao desenvolvimento cultural e socioeconômico e à participação das comunidades" ${ }^{81}$ Com isso, observamos a possibilidade de os Memoriais serem entendidos como instituições museológicas.

Essa análise do Estatuto de Museus coaduna com a perspectiva do ICMEMO, o qual considera que os memoriais desenvolvem a função de museus, com a finalidade de homenagear as vítimas de estado e salvaguardar os direitos humanos básicos.

Assim, Williams reconhece que o termo Museu Memorial representa um tipo específico de museu, dedicado a um evento histórico que comemora o
78. Jeudy (2005, p. 19).

79. Williams (2007).

80. ICOM. Estatutos (2007).

81. Brasil. Lei $\mathrm{n}^{\circ}$ 11.904, de 14 de janeiro de 2009. 
82. "[...]a specific kind of museum dedicated to a historic event commemorating mass suffering of some kind", Williams (2007, p. 8).

83. Williams (2007, p. 8).

84. Williams (2007, p. 8).

85. Brasil. Ministério da Cultura (2007, p. 18).

86. Bondía (2002).

87. Bondía (2002, p. 2).

88. Heidegger (2003).

89. Bondía (2002, p. 25).

90. Williams (2007). sofrimento em massa de algum tipo. ${ }^{82}$ No entanto, o autor problematiza ao considerar que um Memorial é visto "senão apoliticamente, pelo menos um refúgio seguro da história", visto que, segundo a análise do autor, "um museu histórico possui a preocupação com interpretação, contextualização e crítica"83 e o memorial não. $O$ autor conclui ainda que a somatória de museu e memorial "adiciona tanto uma estrutura moral para a narração de terríveis acontecimentos históricos como a contextualização em profundidade para explicações aos atos comemorativos" ${ }^{84}$ Essa afirmativa permite supor que os Museus Memoriais desempenham as atividades de um memorial no âmbito museológico, complementando a ambivalência das duas instituições: museus e memoriais.

\section{Memorial de Imigração Polonesa em Curitiba}

As articulações do museu como instituição de diálogo com a comunidade visam ampliar as relações com seus atores sociais. Além de favorecer o encontro e o reconhecimento do museu com o seu público, por meio de práticas sociais específicas, "os museus conquistaram notável centralidade no panorama político e cultural do mundo contemporâneo [...] Passaram a ser percebidos como práticas sociais complexas". 85

Nesse sentido, percebe-se que o Memorial de Imigração Polonesa possui algumas características que propiciam ao visitante uma nova forma de memorialização, tendo a oportunidade da experiência, da sensibilização, na medida em que o acesso ao ambiente do interior das casas situadas em meio ao bosque remete a um estilo de vida essencialmente rural, em contraponto a uma sociedade urbana e informatizada que cerca o parque.

Jorge Larossa Bondía, ${ }^{86}$ filósofo e professor da Universidade de Barcelona, indica os resultados do enorme volume de informações na sociedade contemporânea: "A informação não é experiência. E mais, a informação não deixa lugar para a experiência, ela é quase o contrário da experiência, quase uma antiexperiência". ${ }^{87}$

O pensamento de Bondía segue Heidegger ${ }^{88}$ ao analisar a experiência no contexto do sujeito "[...] aberto a sua transformação" 89 pela vivência de algo novo. Diante do desdobramento desse conceito para a ambiência do Memorial, permite-se pensar o visitante na perspectiva de sua transformação pela sensibilização, de sujeito passivo para sujeito que percebe e pensa o mundo.

As diversas possibilidades de atuação do MIP como instituição de memória e os delineamentos contemporâneos das instituições museais reportam às tentativas de delimitação de seu campo de trabalho como museu memorial. Nesse sentido, ao retomar a análise de Williams, ${ }^{90}$ quando define os memoriais como locais dedicados a um evento histórico que comemora um sofrimento de massa, não nos parece obviamente adequado, a menos que levemos em conta as dificuldades e sofrimentos passados pelos imigrantes em suas terras natais e que os motivaram a deixá-las, como descrito pela senhora Danuta em sua entrevista, 91 
ou àqueles sofridos ao deixarem sua terra natal e se adaptarem a um novo país, com cultura diversa da sua.

$\bigcirc$ termo Sítio Memorial, também trazido por Williams ${ }^{92}$ como um local cuja função é comemorativa de um evento ali ocorrido, mas que não apresente necessariamente uma estrutura física, parece fora de contexto, na medida em que aquele local não possui ligação anterior com a imigração polonesa, mas foi ali montado a partir de objetos trazidos de outros locais.

Ainda considerando a análise de Williams, ${ }^{93}$ percebe-se a possibilidade de caracterização do MIP como instituição museal, na medida em que elege para suas funções a preservação do acervo de casas de tronco e uma coleção de objetos referentes à imigração polonesa em Curitiba.

Por outro lado, observamos que o Memorial da Imigração Polonesa de Curitiba não se configura na descrição do comitê do ICOM/ICMEMO, por não compreender vítimas de estado. No entanto, o MIP possui, em seu perfil de atuação, a preocupação de "divulgar informação sobre eventos históricos mantendo sua perspectiva histórica e também suas fortes ligações com o presente", 94 ao desenvolver atividades com o intuito de congregar a comunidade polonesa por ocasião de comemorações.

Contribuindo com essa discussão sobre memoriais, a museóloga Ana Maria Vieira analisa que os "Memoriais são monumentos à memória onde a cultura material seria, portanto o meio e não o fim", 95 evidenciando, dessa maneira, que o foco de trabalho dessas instituições estaria substancialmente voltado à identidade coletiva dos sujeitos. Nessa concepção, o memorial abrange as memórias de instituições, personalidades, cidades, fatos, acontecimentos. No mesmo artigo, a autora questiona sobre a existência de um conceito para memorial, bem como propõe e argumenta que "nem todos os museus criam espaços que favorecem a reflexão sobre todas essas questões" $" 96$ como os Memoriais e que são vários os questionamentos sobre a denominação Memorial. A autora reafirma as propostas de memoriais citadas por Williams,

Situados em sítios históricos originais, refletem políticas públicas estratégicas de direitos humanos no âmbito da Justiça e das Relações Internacionais. Envolvem principalmente as questões relacionadas à memória. No caso dos inúmeros memoriais de guerra, estes foram e são erigidos no sentido de reparações ou como espaços de reflexão objetivando a paz.97

Por fim, Barcellos aponta que há "ausência de uma delimitação conceitual" a respeito dos Memoriais, pois estes "derivam dum entendimento sobre o papel que têm as instituições que trabalham com a memória na sociedade" 98

\section{Considerações finais}

Ao longo deste artigo, foram apresentadas considerações a respeito do conceito de memorial, tomando como base o Memorial de Imigração Polonesa em Curitiba. Emergimos as discussões entre memoriais e museus, sua
91. Abreu (2007).

92. Williams (2007).

93. Williams (2007).

94. ICOM/ICMEMO (2001, p. 1).

95. Vieira (2013, p. 2).

96. Vieira (2013, p. 2).

97. Vieira (2013, p. 2).

98. Barcellos (1999, p. 1). 
percepção histórica e aplicação social, na perspectiva de auxiliar a compreensão sobre as potencialidades e possibilidades dessas instituições. Dessa forma, acredita-se que o Memorial de Imigração Polonesa em Curitiba, enquanto espaço de preservação da memória dos imigrantes poloneses, comporta um perfil museológico em potencial.

No decorrer desta narrativa, assinalamos a importância e a complexidade no trato com o patrimônio, objetivando pensá-lo a partir dos sujeitos, das referências culturais de determinado grupo, em contraponto às necessidades do city marketing como estratégia de construção da imagem da cidade.

Nesse cenário, colocamos em pauta a necessidade de se questionar o conceito de memorial utilizado para a implantação daquela instituição ou mesmo se o Memorial da Imigração Polonesa pode ser considerado um museu, como sugerem as atuais definições do Conselho Internacional de Museus - ICOM, e pelo Instituto Brasileiro de Museus - IBRAM.

Extrapolando as barreiras de dinâmica institucional do MIP, abordamos os perfis de atuação dos memoriais na tentativa de delimitação conceitual, exemplificando-se a pluralidade de temas e formatos dessas instituições no âmbito nacional e global.

Na tentativa de categorizar os memoriais, o que corrobora as intenções deste artigo, a somatória de museu e memorial dentro do contexto do MIP permite supor que os Museus Memoriais desempenham as atividades de um memorial no âmbito museológico, confirmando a ambivalência das duas instituições: museus e memoriais.

Com isso, é possível oferecer um olhar diferenciado, por meio do qual analisamos as conexões entre o museu e os memoriais, de modo a estabelecer novas interpretações entre o campo político, a proposta dos memoriais e museus e entre outros fatores, sua interface privilegiada com o poder político. 


\section{REFERÊNCIAS}

\section{FONTES ON LINE}

BOSQUE DO PAPA / Memorial da Imigração Polonesa. Linhas. 25 maio 2011. Disponível em: $<$ http://nossaslinhas.blogspot.com.br/2011/05/o-bosque-que-tambem-sedia-o-memorial-da. html>. Acesso em: 6 nov. 2016.

Brasília reúne atrativos clássicos da arquitetura moderna. Memorial JK. Portal Brasil, 23/2/2015. Disponível em: <http://www.brasil.gov.br/turismo/2015/02/brasilia-reune-atrativosclassicos-da-arquitetura-moderna >. Acesso em 30.05. 2016.

BRASIL. Ministério da Cultura. Política nacional de museus. Brasília: MINC, 2007. Disponível em: <http://www.museus.gov.br/sbm/downloads/politica_nacional_museus.pdf $>$. Acesso em: 2 abr. 2015.

BRASIL. Lei $n^{\circ}$ 11.904, de 14 de janeiro de 2009. Institui o Estatuto de Museus e dá outras providências. Disponível em: <http://www.planalto.gov.br/ccivil_03/_Ato2007-2010/2009/Lei/ L11904.htm>. Acesso em: 6 abr. 2016.

CEQUINEL, L. Memorial da imigração polonesa, bosque do Papa. Disponível em: <https:// br.pinterest.com/pin/360921357617545368/>. Acesso em: 5 ago. 2016.

CURITIBA. Galeria de Imagens. Disponível em: <http://www.curitiba.pr.gov.br/fotos/ album-portal-polones-marca-historia-da-imigracao-desse-povo-a-curitiba/24220>. Acesso em: 6 nov. 2016.

Curitiba para não curitibanos. Disponível em: <http://curitibaparanaocuritibanos.blogspot. com.br/2011/05/bosque-do-papa-joao-paulo-ii.html>. Acesso em: 6 nov. 2016.

FIGUNDIO, André. Bosque do Papa em Curitiba: um passeio cultural, divertido e gratuito. Disponível em: <http://euqueroeviajar.blogspot.com.br/2012/04/bosque-do-papa-em-curitibaum-passeio.html>. Acesso em: 5 abr. 2016.

FUNDAÇÃO CULTURAL DE CURITIBA. Termo de Cooperação que fazem entre si a Fundação Cultural de Curitiba e a Missão Católica Polonesa no Brasil. Curitiba,1987. Documento digitalizado e não publicado.

IBRAM. Cadastro Nacional de Museus. Disponível em: <http://sistemas.museus.gov.br/cnm/ pesquisa/filtrarUf>. Acesso em: 30 maio 2016.

ICOM. Declaração de Santiago: princípios-base do museu integral. 1972. Disponível em: $<$ http://www.fcc.sc.gov.br/patrimoniocultural/pagina/12364/declaracaodesantiago 1972principios-basedomuseuintegral>. Acesso em: 9 jul. 2015. 
Estatutos. In: ASSEMBLEIA GERAL, 22. Viena, 2007. Anais... Viena, 2007. Disponível em: <http://icom.org.br/wp-content/themes/colorwaytheme/pdfs/ código\%20de\%20etica/ codigo_de_etica_lusofono_iii_2009.pdf>. Acesso: 15 maio 2015.

ICOM/ICMEMO. Rules of the International Committee of Memorial Museums for the remembrance of victims of public crimes. 2001. Disponível em: <http://network.icom.museum/ fileadmin/user_upload/minisites/icmemo/pdf/rulesIC_MEMO.pdf>. Acesso em: 2 abr. 2016.

JORNAL DO ESTADO. Tomás Coelho vê seu final com a chegada das águas. Curitiba, p. 12, 1 fev. 1987. Exemplar avulso. Acervo da Casa da Memória de Curitiba. Pasta s.n. [Memorial da Imigração Polonesa].

Desvio antecipado do Passaúna surpreende moradores. Curitiba, p.1, 1 fev. 1987. Exemplar avulso. Acervo da Casa da Memória de Curitiba. Pasta s.n. [Memorial da Imigração Polonesa].

MEMORIAL da Resistência de São Paulo. Portal do Governo. Disponível em: <www. memorialdaresistenciasp.org.br>. Acesso em: 30 jun. 2016.

MORIN, Violaine. Le musée du 11 Septembre de New York fait déjà polémique. Journal Le Figaro. 14/5/2014. Disponível em: <http://www.lefigaro.fr/culture/2014/05/14/0300420140514ARTFIG00278-le-musee-du-11-septembre-de-new-york-fait-deja-polemique.php > Acesso em: 30 jul. 2016.

9/11 MEMORIAL. Disponível em: <https://www.911memorial.org/exhibitions>. Acesso em: 5 ago. 2016.

OBAMA, Barack. Remarks by the President at 9/11 Museum Dedication. Disponível em: <https:// www.whitehouse.gov/thepressoffice/2014/05/15/remarkspresident911museumdedication>. Acesso em: 30 jun. 2016.

RECONSTRUÇÃO transformou Hiroshima em 'cidade da paz'. iG São Paulo. 12/02/2010. Disponível em: <http://ultimosegundo.ig.com.br/reconstrucao/reconstrucao-transformouhiroshima-em-cidade-da-paz/n1237592457675.html>. Acesso em: 30 jul. 2016.

\section{LIVROS, ARTIGOS E TESES}

BARCELLOS, Jorge. O Memorial como instituição no sistema de museus: Conceitos e práticas de um conteúdo. Versão modificada da palestra apresentada no Fórum Estadual de Museus, Porto Alegre, 1999. Disponível em: <http://www.memorial.mppr.mp.br/arquivos/File/ Barcellos.pdf>. Acesso em: 28 jun. 2016.

BONDÍA, Jorge Larrosa. Notas sobre a experiência e o saber de experiência. Revista Brasileira de Educação, Rio de Janeiro, n. 19, p. 20-28, jan./abr. 2002. Disponível em: <http://www. scielo.br/pdf/rbedu/n19/n19a02.pdf>. Acesso em: 28 out. 2015. 
BURKE, Peter. História como memória social. In: Variedades de bistória cultural. Rio de Janeiro: Civilização Brasileira, 2000. p. 67-89.

CANDAU, Joël. Memória e identidade. São Paulo: Contexto, 2011.

CHAGAS, Mário de Souza. Memória e Poder: dois movimentos. Cadernos de Sociomuseologia, 19, p. 43-81 Jun. 2009. Disponível em: <http://revistas.ulusofona.pt/index.php/ cadernosociomuseologia/article/view/367/276>. Acesso em: 10 out. 2016.

COROMINES, Jordi Guixé i. El Memorial Democrático y los lugares de la memoria: la recuperación del patrimonio memorial en Cataluña. Entelechya Revista Interdisciplinar. Cataluña. n.7, 217-228, set. 2008. Disponível em: <http://www.eumed.net/entelequia/ pdf/2008/e07a12.pdf>. Acesso em: 30 jun. 2016.

DOUSTDAR, Neda Mohtadi. Imigração polonesa: raízes históricas de um preconceito. 1990. 169 f. Dissertação (Mestrado) - Universidade Federal do Paraná, Curitiba, 1990.

FIGUEIREDO, Betânia Gonçalves e VIDAL, Diana Gonçalves (orgs.). Museus. Dos gabinetes de curiosidades à museologia moderna. Belo Horizonte: ARGUMENTUM, 2005.

FREITAS, Moacir Fagundes. Museu de cidade: Entrecruzando patrimônio e cidades. Múltiplos Olhares em Ciência da Informação, v. 4, n.1, p.1-8, mar. 2014. Disponível em: <http:// portaldeperiodicos.eci.ufmg.br/index.php/moci/article/view/1907>. Acesso em: 15 jun. 2015.

FUNDAÇÃO OSWALDO CRUZ. Política de preservação e gestão de acervos culturais das ciências. Rio de Janeiro: Fiocruz/COC, 2013. 26p. Disponível em: <http://www.coc.fiocruz.br/ images/PDF/politica_preservacao_gestao_acervos_coc.pdf > Acesso em: 30 maio 2015.

GARCIA, Fernanda Ester Sanchez. Políticas urbanas em renovação: uma leitura dos modelos emergentes. Revista Brasileira de Estudos Urbanos e Regionais, Campinas, n.1, p.115-132, 1999. Disponível em: <http://unuhospedagem.com.br/revista/rbeur/index.php/rbeur/article/ view/13/1>. Acesso em: 20 maio 2016.

O City Marketing de Curitiba diante das novas realidades mundiais. V Encontro Nacional da Anpur. Anais. Brasília, DF,1995. Disponível em: <http://unuhospedagem.com.br/ revista/rbeur/index.php/anais/article/view/1669/1643>. Acesso em: 30 jun. 2016.

GARCIA. Fernanda Ester Sanchez; MOURA, Rosa. Cidades-modelo: espelhos de virtudes ou reprodução do mesmo? Cadernos IPPUR, Rio de Janeiro, Ano XIII, n. 2, 1999, p. 95-114. Disponível em: <https://drive.google.com/file/d/0By1DYFPclamKaW5LOTJQN1VzOWM/view? pli=1>. Acesso em: 12 jan. 2016.

GEERTZ, Clifford James. A interpretação das culturas. Rio de Janeiro: LTC, 2011.

GEISSLER, Helenne Jungblut. Análise de critérios para localização de áreas verdes urbanas de Curitiba-PR. Estudo de caso: Bosque do Papa e Parque Barigüi. Florianópolis. 2004. $274 \mathrm{f}$. Dissertação (Mestrado em Engenharia Civil) - Programa de Pós-Graduação em Engenharia Civil, Universidade Federal de Santa Catarina, Florianópolis, 2004. Disponível em: <https:// repositorio.ufsc.br/handle/123456789/101552>. Acesso em 18 jun. 2015. 
GIL FILHO, Sylvio Fausto. Colônia polonesa e o processo de metropolização de Curitiba: impactos espaciais da modernidade. Dissertação de Mestrado em Geografia. Universidade Estadual Paulista. Rio Claro, SP. 1994. Disponível em: <http://www.faustogil.ggf.br/gilfilho/ arquivos/Colonia_Polonesa.pdf>. Acesso em: 30 jun. 2016.

GONÇALVES, José Reginaldo Santos. Os museus e a representação do Brasil. Revista do Patrimônio Histórico e Artístico Nacional, Rio de Janeiro, v. 31, p. 254-273, 2005. Disponível em: <http://portal. iphan.gov.br/uploads/publicacao/RevPat31_m.pdf>. Acesso em: 18 jun. 2015.

HEIDEGGER, Martin. A caminho da linguagem. Petrópolis: Vozes. 2003

HUYSSEN, Andreas. Seduzidos pela memória: arquitetura, monumentos, mídia. Rio de Janeiro: Aeroplano, 2000.

JEUDY, Henri-Pierre. Espelho das cidades. Rio de Janeiro: Casa da Palavra, 2005.

Memórias do social. Rio de Janeiro: Forense Universitária,1990.

MARANHÃO, Marlene. A morte líquida. Folha de Londrina. Londrina. 24/04/1985.

MARTINS, Ana Rita Nunes Lopes. A musealização de heranças difíceis: o caso do Museu do Aljube - Resistência e Liberdade. Faculdade de Ciências Humanas e Sociais. Universidade Nova de Lisboa. Dissertação de Mestrado em Museologia. Lisboa. 2015. Disponível em: <https://run. unl.pt/handle/10362/18144>. Acesso em 2 jan. 2016.

MENESES, Ulpiano Bezerra de. O museu na cidade X a cidade no museu: para uma abordagem histórica dos museus da cidade. In: Revista Brasileira de História. São Paulo, v.5, n.8/9. p.197205. Set.1984/abr.1985. Disponível em: <www.anpuh.org/arquivo/download?ID_ ARQUIVO=1912>. Acesso em 30 jun. 2016.

OLIVEIRA, Denilson. Curitiba e o mito da cidade modelo. Curitiba: Editora UFPR, 2000. Disponível em: <http://www.mobilizacuritiba.org.br/files/2014/04/Curitiba-constru\%C3\%A7\%C3\%A3o-edesconstru\%C3\%A7\%C3\%A3o-de-um-mito.pdf>. Acesso em: 30 jul. 2016.

OLIVEIRA, Márcio. Os poloneses do Paraná (Brasil) e a questão da nacionalização dos imigrantes (1920-1945). In: SIMPÓSIO NACIONAL DE HISTÓRIA, 25. 2009, Fortaleza. Anais... Fortaleza, 2009. Disponível em: <http://anais.anpuh.org/wp-content/uploads/mp/pdf/ANPUH. S25.0879.pdf>. Acesso em: 30 jul. 2016.

PARANÁ. Secretaria de Cultura. Espirais do tempo: bens tombados do Paraná. Curitiba: Imprensa Oficial, 2006.

POULOT, Dominique. Museu e museologia. Belo Horizonte: Autêntica, 2013.

ROVIRA, Nuria Benach; GARCÍA, Fernanda Sanchez. Políticas urbanas y producción de imágenes de la ciudad contemporânea: un análisis comparativo entre Barcelona y Curitiba. In: CARRIÓN, Fernando; WOLLRAD, Dörte (Orgs.). La ciudad, escenario de comunicación. Equador: Flacso, 1999. Disponível em: <http://www.flacsoandes.org/ biblio/shared/exist_view. php?bibid=8810\&copyid=103812\&tab=opac $>$. Acesso em: 24 fev. 2013. 
SANCHEZ, Fernanda. A reinvenção das cidades na virada do século: agentes, estratégias e escalas de ação política. Revista de Sociologia e Política, Curitiba, v. 16, p. 31-49, jun. 2001. Disponível em: <http://www.scielo.br/pdf/rsocp/n16/a03n16.pdf>. Acesso em: 30 maio 2016.

URBAN, João. Tu I Tam = Aqui e Lá. Memória da imigração polonesa no Paraná. Primeiro de Maio/PR: Mirabilia, 2004.

VIEIRA, Ana Maria da Costa Leitão. Os Memoriais são um novo gênero de museu? Disponível em: <http://revistamuseu.com/18demaiode2013/artigos.asp?id=28640>. Acesso em: 30 jun. 2016.

WILliAMS, Paul. Memorial Museums: The Global Rush to Commemorate Atrocities. Oxford, UK: Berg, 2007.

WINBERRY, J.J. The log house in Mexico. Annals of the Association of American Geographers. v. 64, n.1. U.S.A., 1974. Disponível em: <http://onlinelibrary.wiley.com/ doi/10.1111/j.1467-8306.1974.tb00954.x/abstract>. Acesso em: fev. 2016.

\section{ENTREVISTAS}

ABREU, Danuta Lisicki de. Danuta Lisicki de Abreu: depoimento [2007]. Entrevistador: Edson Zucchi. Curitiba: Memorial de Imigração Polonesa. 2007. $31 \mathrm{~min}$. Vídeo. Entrevista concedida ao programa Persona da TV UFPR. Disponível em: <http://acervodigital.ufpr.br/ handle/1884/34284>. Acesso em: 24 nov. 2016.

LARA, Maria Daici Gonçalves de. Maria Daici Gonçalves de Lara: depoimento [out. 2015]. Entrevistadora: Gina Esther Issberner. Curitiba: Casa da Memória. 2015. 15 min. MP3. Entrevista concedida ao projeto Representações Sociais dos poloneses no Memorial da Imigração Polonesa em Curitiba.

PIRES, Sérgio Povoa. Sergio Povoa Pires. Depoimento [mar. 2016]. Entrevistadora: Gina Esther Issberner. Curitiba: Instituto de Pesquisas e Planejamento de Curitiba. 2016. 28 min. Fita M60. Entrevista concedida ao projeto Representações Sociais dos poloneses no Memorial da Imigração Polonesa em Curitiba.

Artigo apresentado em 23/08/2016. Aprovado em 05/12/2016. 